\title{
New profiling and mooring records help to assess variability of Lake Issyk-Kul and reveal unknown features of its thermohaline structure
}

\author{
Peter O. Zavialov ${ }^{1}$, Alexander S. Izhitskiy ${ }^{1}$, Georgiy B. Kirillin ${ }^{2}$, Valentina M. Khan ${ }^{3}$, Boris V. Konovalov ${ }^{1}$, \\ Peter N. Makkaveev ${ }^{1}$, Vadim V. Pelevin ${ }^{1}$, Nikolay A. Rimskiy-Korsakov ${ }^{1}$, Salmor A. Alymkulov ${ }^{4,5}$, and \\ Kubanychbek M. Zhumaliev ${ }^{4}$ \\ ${ }^{1}$ Shirshov Institute of Oceanology, Moscow, 117997, Russia \\ ${ }^{2}$ Leibnitz Institute of Freshwater Ecology and Inland Fisheries, 12587 Berlin, Germany \\ ${ }^{3}$ State Hydrometeorological Research Center, Moscow, 123242, Russia \\ ${ }^{4}$ International University of Innovative Technologies, Bishkek, 119991, Kyrgyzstan \\ ${ }^{5}$ Instutute of Physical and Technical Problems and Material Science, Bishkek, 720071, Kyrgyzstan
}

Correspondence: Peter O. Zavialov (peter@ocean.ru)

Received: 9 August 2018 - Discussion started: 18 September 2018

Accepted: 15 November 2018 - Published: 6 December 2018

\begin{abstract}
This article reports the results of three field campaigns conducted in Lake Issyk-Kul in 2015, 2016, and 2017. During the campaigns, CTD profiling and water sampling were performed at 34 locations all over the lake. A total of 75 CTD profiles were obtained. Some biogeochemical and thermohaline parameters at the lake surface were also mapped at high horizontal resolution along the ship's track. In addition, thermistor chains were deployed at three mooring stations in the eastern littoral region of the lake, yielding 147-day-long records of temperature data. The measurements revealed that - while the thermal state of the active layer, as well as some biogeochemical characteristics, were subject to significant interannual variability mediated by atmospheric forcing - the haline structure of the entire lake was remarkably stable at the interannual scale. Our data do not confirm the reports of progressive warming of the deep Issyk-Kul waters as suggested in some previous publications. However, they do indicate a positive trend of salinity in the lake's interior over the last 3 decades. A noteworthy newly found feature is a weak but persistent salinity maximum below the thermocline at a depth of 70-120 m, from where salinity slightly decreased downwards. The data from the moored thermistor chains support the previously published hypothesis about the significant role of the submerged ancient riverbeds on the eastern shelf in advecting littoral waters into the deep portion of the lake during differential cooling period. We hypothesize that the less saline littoral water penetrating into the deep layers due
\end{abstract}

to this mechanism is responsible for the abovementioned features of salinity profile, and we substantiate this hypothesis by estimates based on simple model assumptions.

\section{Introduction}

With its volume of $1730 \mathrm{~km}^{3}$, Lake Issyk-Kul is the tenthlargest lake by volume on Earth overall and the secondlargest mountain lake. It is also the sixth-deepest lake of the world. Amazingly enough, even until recently, the information on the maximum depth of the lake in the available literature has been contradictory. For example, the official navigation map published by the USSR General Staff in 1978 indicated $663 \mathrm{~m}$; Hofer et al. (2002) suggested $650 \mathrm{~m}$; a value of $668 \mathrm{~m}$ was given by Giralt et al. (2002) and a number of other publications; and some authors (e.g., Alamatov and Mikkola, 2011), as well as assorted sources on the Internet, including the Russian-language Wikipedia, give a value of $702 \mathrm{~m}$. However, the most plausible is the maximum depth of $668 \mathrm{~m}$, as it was established based on high-quality echo-sounding data (De Batist et al., 2001).

As an enclosed terminal water body, Lake Issyk-Kul is sensible to climate change in its catchment area. Some summarizing estimates of the water budget components can be found in Romanovsky (2002) and Kulenbekov and Merkel (2012), for example; however, there are large uncertainties 
in all components. From 1927 to 1997, the Issyk-Kul water level decreased by $3.4 \mathrm{~m}$, and it then increased by about $1 \mathrm{~m}$ from 1997 on (e.g., Romanovsky et al., 2013). The effects of climate change on the thermohaline structure of the lake are less well documented because the data are sparse, especially those for the last 3 decades. However, Romanovsky et al. (2013) reported a positive trend of temperature in the deep layers of almost $0.5^{\circ} \mathrm{C}$ for the period 1983-2003, along with substantial increase of surface temperature and river discharge. The interannual and interdecadal variability of salinity in the Issyk-Kul is largely unknown.

The Issyk-Kul is an oligotrophic lake (and, according to the classification of some authors, even ultra-oligotrophic). The level of primary production in it and the concentration of phytoplankton biomass are 10-40 times lower than those characteristic of the world ocean on average (e.g., Antal, 2000). This affects all parts of the food chain and is reflected in the relatively low biodiversity (Mikkola, 2012). The potential of biological productivity of aquatic objects is often quantified by the ratio of the amount of incoming nutrients to the total volume of water. Since the Issyk-Kul water volume is very large, and the supply of nutrients is restricted to the inflow from relatively small rivers, the oligotrophy of the lake is easily explained from this point of view. However, this argumentation is valid only if the nutrients are distributed throughout the entire water mass of the lake; if, however, most of the nutrients are retained in the upper euphotic layer, the expectancy of biological productivity improves significantly. Thus, the nutrient budgets and biological productivity of the Issyk-Kul are intimately connected with the mixing regimes of the lake. It has been shown by tracer analysis methods that vertical mixing of the Issyk-Kul at the interannual scale is very intense and deep waters renew rapidly, with residence time of only about 11 years or less (Hofer et al., 2002). The question about the mechanisms of such a fast renewal remains open.

An important role in the horizontal and vertical exchanges of the Issyk-Kul waters may belong to peculiar features of the bottom relief, in particular, the submerged beds of paleorivers on the extensive eastern shelf of the lake. It is well established that the Issyk-Kul has experienced regressions and transgressions of up to $400 \mathrm{~m}$ in the past (e.g., Gebhardt et al. 2017). In particular, during the late Pleistocene, the IssykKul level was about $100 \mathrm{~m}$ below the current standing. At that time, today's shallow areas in the eastern and western parts of the lake were land. The rivers presently known as the Jyrgalan and the Tyup have left channels, or canyons, on today's lake bottom, buried $20-70 \mathrm{~m}$ below the surrounding flat landscape. These channels are well preserved and distinctly visible over many kilometers. At the shelf break, the channels connect to the deep central part of the lake. According to the hypothesis put forward by Peeters et al. (2003), mixing of the lake at seasonal timescales begins in autumn with differential cooling, when the water in the shoals cools to lower temperatures than that in the deep part of the Issyk-Kul. Further, due to density convection, this cold water descends into the submerged riverbeds on the shelf, along which it then flows downslope to the deep part of the lake and sinks there to its isopycnic level in the abyssal layers. This hypothesis, however, is yet to be confirmed by direct measurements.

Lake Issyk-Kul is of general scientific interest also because its bottom sediment deposits potentially hold unique information on climate change in continental Eurasia spanning millions of years. The possibility of organizing deep drilling in the Issyk-Kul in order to collect cores providing a climate reconstruction for 200 000-300 000 years has been widely discussed (e.g., Oberhänsli and Molnar, 2012). In this context, in order to determine the most informative locations for prospective drilling and correctly interpret the results, it is necessary to understand well the features of the Issyk-Kul hydrology and the processes of suspended matter transport in the lake's water mass.

Lake Issyk-Kul has attracted researchers for centuries, and the most intense studies were underway in the decades of the 1950s through the 1980s. Much of the data obtained at that time were summarized in monographs by Kadyrov (1986), focused on hydrochemical issues, and by Romanovsky (1991), centered on the hydrology of the lake. Both books, however, were published in Russian in small series and have now become bibliographic rarities. The amount of data collected from the Issyk-Kul decreased dramatically in the 1990s after the disintegration of the USSR. In the 2000s and 2010s, a handful of field campaigns in the lake took place within some international projects. However, overall, the data coverage remains very sparse. This especially applies to salinity data. During the Soviet era, salinity was determined mainly analytically from water samples, either as a sum of ions or through the dry residue method. This approach yielded a wealth of robust data, but their precision and spatial resolution were insufficient, especially considering that salinity variations in the Issyk-Kul, both spatial and temporal, are generally small. Nowadays, CTD profiling is used, but converting conventional CTD data to true salinity is not straightforward because of the ionic composition of Issyk-Kul water, which is significantly different from that of ocean water. An empirical formula derived from highaccuracy laboratory measurements was proposed by Peeters et al. (2003), who conducted two rather extensive CTD surveys of the lake in the early 2000s, but the conversion has not been widely used since then.

In the present paper, we report principal findings of three recent field campaigns, focusing on thermohaline structure and its variability. We use the abovementioned empirical formula to obtain and investigate the true salinity fields. We also address hydrochemical parameters. In a separate section, we analyze water temperature records from thermistor chains deployed inside and outside the submerged riverbeds on the shelf during the cooling period in an attempt to quantify the role of the river canyons in advecting the cold water on the shelf towards the deep basin. 


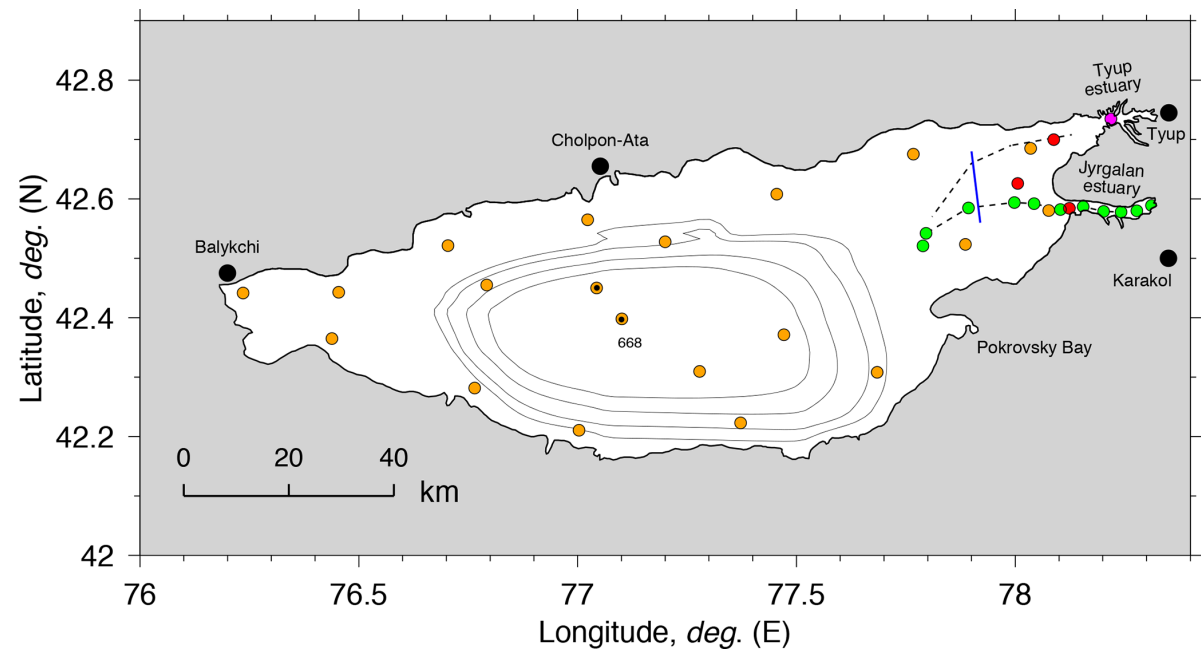

Figure 1. Map of Lake Issyk-Kul with schematized bathymetry contours 200, 300, 400, and 500 m, and hydrographic stations occupied during the field campaigns of June 2015, November 2016, and June 2017. Most stations were occupied during all surveys (orange bullets). Green bullets show stations occupied only once in 2016, and the magenta bullet depicts the station occupied only once in 2017. The red bullets mark the locations of the mooring stations. The orange bullets with dots inside refer to the deepest stations; see Fig. 2. The dashed lines in the eastern part of the lake indicate the paleo-beds of the Jyrgalan and Tyup rivers; see the text for details. The blue segment shows the location of bathymetric transect discussed in Sect. 3.4 and depicted in Fig. 14.

\section{Data}

The data used in this study were collected in three consecutive cruises of the R/V Moltur. The first survey took place on 23 June through 27 June 2015, the second on 31 October through 3 November 2016, and the third on 25 June through 1 July 2017. CTD profiling and water sampling were performed at 34 locations all over the lake (Fig. 1). A total of 75 CTD profiles were obtained. A shallow-water CTD instrument (YSI6600) was used in 2015, so profiling in this survey was confined to the uppermost portion $(70 \mathrm{~m})$ of the water column. In the surveys of 2016 and 2017, a SeaBird SBE 19plus Seacat instrument allowing for deep profiling was used. According to the manufacturer's specifications, the profiler has an accuracy of $0.005^{\circ} \mathrm{C}$ and $0.0005 \mathrm{~S} \mathrm{~m}^{-1}$, and resolution of $0.0001{ }^{\circ} \mathrm{C}$ and $0.00005 \mathrm{~S} \mathrm{~m}^{-1}$, in temperature and conductivity, respectively. Because of drift of the vessel, leading to inclination of the line, the maximum depths achieved were $570 \mathrm{~m}$ in 2016 and $481 \mathrm{~m}$ in 2017. In this study, as far as the CTD data are concerned, we mainly focus on the deep stations, as well as those in the area adjacent to the river mouths in the eastern littoral region. Water samples were taken using HydroBios $5 \mathrm{~L}$ Niskin bottles in all surveys at all stations at different depth levels from the surface to the bottom, with the depth increment varying from 20 to $50 \mathrm{~m}$. The samples were analyzed in the laboratory using standard techniques (Winkler method for oxygen; potentiometric method for $\mathrm{pH}$; titration method for alkalinity; colorimetric assay method for phosphates, silicates, nitrates, and nitrites).
In addition to the measurements at stations and moorings, continuous measurements of chlorophyll $a$ and total suspended matter using an Ultraviolet Fluorescence LiDAR (UFL-9) were conducted along the ship's track. The details of the lidar and methodology of this kind of measurements providing horizontal resolution of about $10 \mathrm{~m}$ were described by Palmer et al. (2013), Pelevin et al. (2017), and Zavialov et al. (2018). Along with the lidar measurements, water samples were collected at all stations and analyzed for concentrations of suspended matter and chlorophyll through the procedures described by Konovalov et al. (2014). The pigment carotenoid-chlorophyll index (CCI) showing essentially the "age" or the life stage of the phytoplankton was also determined photometrically in the laboratory as the ratio of optical densities of pigments extracted from the samples at 430 and $665 \mathrm{~nm}$ wavelengths (e.g., Margalef, 1967; Wozniak and Dera, 2007).

In the cruise of 2016, the continuous along-track measurements also included soundings of temperature and electric conductivity in the uppermost layer using a pump-through system and the shipboard YSI6600 CTD instrument, which allowed for horizontal resolution in the along-track direction on the order of $100 \mathrm{~m}$. As mentioned above, in all cases we used the empirical formula proposed by Peeters et al. (2003) to infer salinity from temperature, electric conductivity, and pressure.

Moreover, three mooring stations equipped with thermistor chains were deployed on 1 November 2016 and then recovered on 27 March 2017. Hence, the stations functioned for 147 days, registering water temperature at different depth levels as $1 \mathrm{~min}$ averages. At the southern mooring station de- 
ployed in the paleo-bed of the Jyrgalan River, where the total depth was $50.7 \mathrm{~m}, 13$ RBR TR-1060 temperature sensors were installed at depth levels of 1, 6, 12, 16, 20, 24, 29, 32, $38,42,46,48$, and $49 \mathrm{~m}$, and one RBR TDR-2050 temperature and pressure sensor at $51 \mathrm{~m}$ depth. At the northern mooring in the Tyup River paleo-bed at a depth of $50 \mathrm{~m}$, four RBR TR-1060 thermistors were fixed only in the lower portion of the water column at the levels 20,30,40, and $50 \mathrm{~m}$. Finally, at the reference mooring station between the two channels at a depth of $23 \mathrm{~m}$, three RBR TR-1060 temperature sensors were installed at 3,10 , and $17 \mathrm{~m}$, and one RBR TDR-2050 sensor at $23 \mathrm{~m}$ depth. Prior to the deployment of the moorings, bathymetry mapping was conducted using a FortXXIScat300 two-beam echo sounder to obtain detailed bottom topography.

\section{Results and discussion}

\subsection{Vertical thermohaline structure and its variability}

The vertical structure of temperature and salinity as observed on 31 October 2016 and 29 June 2017 in the deepest area of the Issyk-Kul is shown in Fig. 2. The two stations where the CTD profiles were obtained are shown by orange bullets with black dots inside in Fig. 1. As mentioned above, in 2016, the instrument reached a depth of $570 \mathrm{~m}$, while in 2017 we were only able to obtain the profiles to a depth of $481 \mathrm{~m}$. Prior to plotting the salinity data, the data were smoothed using $6 \mathrm{~m}$ wide boxcar filtering to remove spikes.

Also shown in Fig. 2 are the respective historical data from literature sources. The newly obtained data indicate that significant interdecadal warming of deep waters of the lake reported by Romanovsky et al. (2013) as about $0.25^{\circ} \mathrm{C}$ per decade for the period 1983-2003 is apparently no longer occurring, as the present-day temperature at $500 \mathrm{~m}$ depth is exactly the same as it was in 2003 (namely, $4.44{ }^{\circ} \mathrm{C}$ ). We did observe positive trend of salinity in deep waters, where it has increased by about $0.05 \mathrm{~g} \mathrm{~kg}^{-1}$ since 1984 , and about $0.02 \mathrm{~g} \mathrm{~kg}^{-1}$ since 2001. However, according to the literature data (Kadyrov, 1986), in 1947 the near-bottom salinity was as high as $6.11 \mathrm{~g} \mathrm{~kg}^{-1}$, which is about $0.09 \mathrm{~g} \mathrm{~kg}^{-1}$ higher than it is now. The data of 2001 as reported by Peeters et al. (2003) were derived from CTD profiling using exactly the same approach as used in this study (in fact, we adopted here the approach and procedure of Peeters et al., 2003). Therefore, the comparability of our recent data with those of 2001 should raise no doubt. The earlier salinity data of 1947 and 1984 were obtained through a different approach from laboratory measurements based on either dry residue or a sum-ofions method (Kadyrov, 1986). However, this author claimed an accuracy of $0.01 \mathrm{~g} \mathrm{~kg}^{-1}$. Hence, the comparison with our data is justified, as it revealed the differences significantly larger than this accuracy limit.
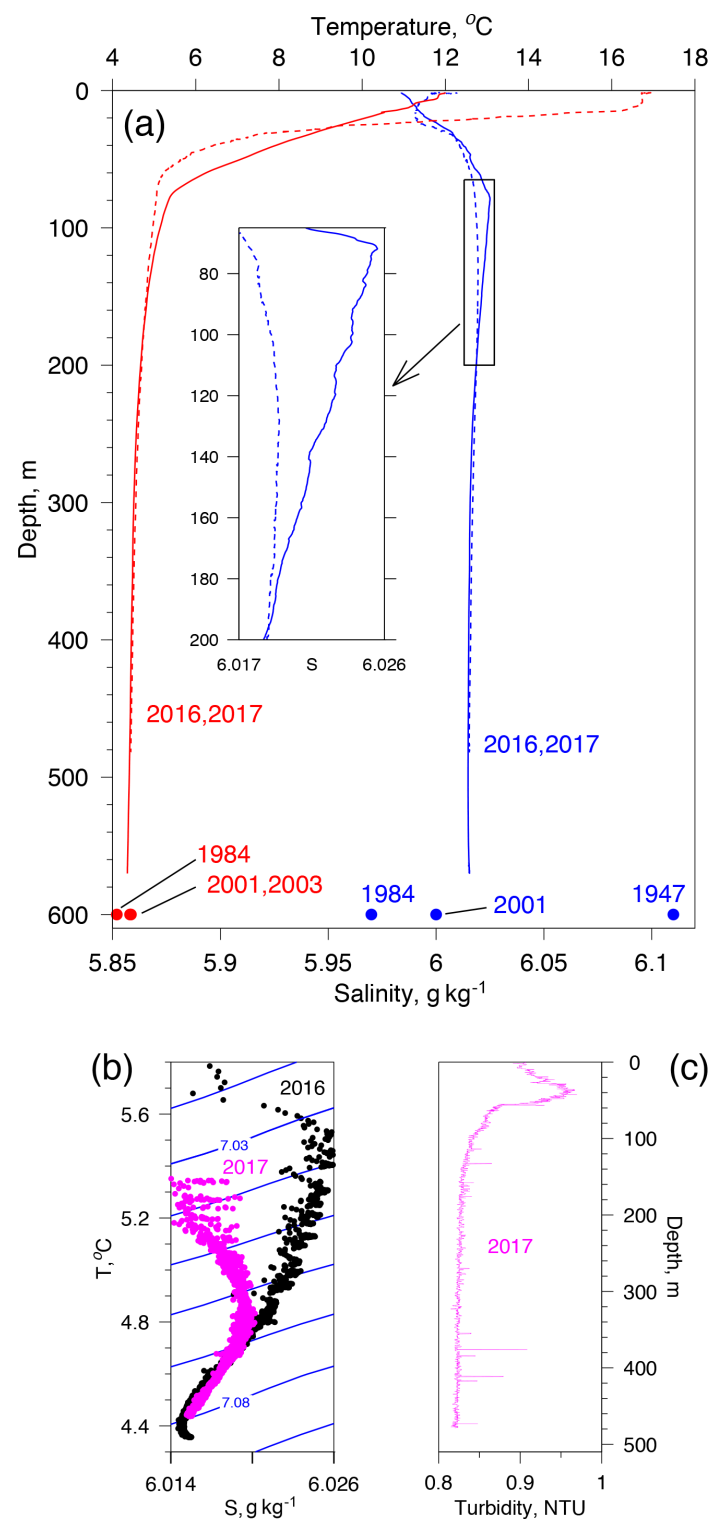

Figure 2. (a) Vertical profiles of temperature (red) and salinity (blue) observed on 31 October 2016 at $42.450^{\circ} \mathrm{N}, 77.044^{\circ} \mathrm{E}$ (solid), and on 29 June 2017 at $42.397^{\circ} \mathrm{N}, 77.100^{\circ} \mathrm{E}$ (dashed), and a summary of available historical data for different years based on Kadyrov (1986), Romanovsky (1991), Peeters et al. (2003), and Romanovsky et al. (2013). (b) TS diagrams for water below the thermocline for October 2016 (black) and June 2017 (magenta); the blue lines are density $\left(\rho-1000 \mathrm{~kg} \mathrm{~m}^{-3}\right)$ isopleths for 40 bar pressure calculated using the empirical formula by Peeters et al. (2003). (c) Vertical profile of turbidity in June 2017.

The recent temperature profiles (red curves in Fig. 2a) include a rather steep thermocline, where temperature dropped from about $12^{\circ} \mathrm{C}$ in 2016 and $17^{\circ} \mathrm{C}$ in 2017 near the surface to about $5^{\circ} \mathrm{C}$ at a depth of 80 and $60 \mathrm{~m}$, respectively. Farther towards the bottom, the temperature decreases only slightly to $4.44^{\circ} \mathrm{C}$ at a depth of $480 \mathrm{~m}$ and to $4.37^{\circ} \mathrm{C}$ at a 
depth $570 \mathrm{~m}$. The differences between the profiles of 2016 and 2017 practically vanished at depths below $180 \mathrm{~m}$.

The salinity profiles (blue curves in Fig. 2a) are somewhat more complex than the temperature ones, although the range of salinity change in the vertical direction is quite small all values lie within the interval smaller than $0.07 \mathrm{~g} \mathrm{~kg}^{-1}$ between 5.960 and $6.026 \mathrm{~g} \mathrm{~kg}^{-1}$. In 2016, salinity increased from $5.960 \mathrm{~g} \mathrm{~kg}^{-1}$ at the surface to $6.026 \mathrm{~g} \mathrm{~kg}^{-1}$ at $81 \mathrm{~m}$ and then decreased towards the bottom to $6.015 \mathrm{~g} \mathrm{~kg}^{-1}$ at $570 \mathrm{~m}$. In 2017 , salinity first decreased from about $5.996 \mathrm{~g} \mathrm{~kg}^{-1}$ at the surface to a minimum of $5.990 \mathrm{~g} \mathrm{~kg}^{-1}$ at the upper edge of the thermocline at a depth of $15.5 \mathrm{~m}$ and then increased downwards slightly until it attained the maximum value of $6.019 \mathrm{~g} \mathrm{~kg}^{-1}$ at a depth of about $125 \mathrm{~m}$ (see the inset panel in Fig. 2). From there and down to the bottom, the salinity was almost constant, but it showed an extremely slight decrease to $6.015 \mathrm{~g} \mathrm{~kg}^{-1}$ at a depth of $481 \mathrm{~m}$.

Therefore, we report here the existence of very weak but observable salinity maximum at intermediate depths below the thermocline. This maximum is too small in magnitude to have been detected by techniques used in the Soviet period of the lake's exploration, so it was never reported at that time. However, the magnitude $\left(0.004\right.$ to $\left.0.011 \mathrm{~g} \mathrm{~kg}^{-1}\right)$ is much larger than the instrumental uncertainty of CTD measurements, which can be estimated from instrument specifications and Peeter's formula as about $0.001 \mathrm{~g} \mathrm{~kg}^{-1}$ or smaller. The maximum appears to be a robust and persistent feature a similar behavior of salinity was evident in the data of 2001 presented by Peeters et al. (2003), although these authors did not discuss the intermediate salinity maximum explicitly. In their observations, the depth of the maximum varied from 200 to $300 \mathrm{~m}$, and then below this layer the salinity decreased slightly by about $0.002 \mathrm{~g} \mathrm{~kg}^{-1}$ towards the bottom.

The temperature-salinity (TS) diagrams for waters below the thermocline for 2016 and 2017 shown in Fig. $2 b$ also clearly indicate the intermediate salinity maxima at $5.5^{\circ} \mathrm{C}$, $6.026 \mathrm{~g} \mathrm{~kg}^{-1}$ for 2016 , and $4.8^{\circ} \mathrm{C}, 6.02 \mathrm{~g} \mathrm{~kg}^{-1}$ in 2017 . It is interesting that in the deepest layer there is a hint of salinity increase below $4.38^{\circ} \mathrm{C}$, that is, below $540 \mathrm{~m}$.

The observed salinity inversions are very small in magnitude and do not have any significant effect on density as compared to the effect of temperature stratification, so the water column remains convectively stable. The possible dynamical origin of the intermediate salinity maximum beneath the thermocline will be discussed below in the subsection dedicated to winter cooling on the eastern shelf.

The vertical profile of turbidity obtained in June 2017 is exhibited in Fig. 2c. It shows a distinct maximum at a depth of about $40 \mathrm{~m}$ at the upper edge of the thermocline, likely associated with the maximum concentration of phytoplankton (see also Fig. 13). Under the thermocline, turbidity decreased downwards and was nearly constant below $200 \mathrm{~m}$, although some spike-like positive anomalies were seen in the lower portion of the water column.
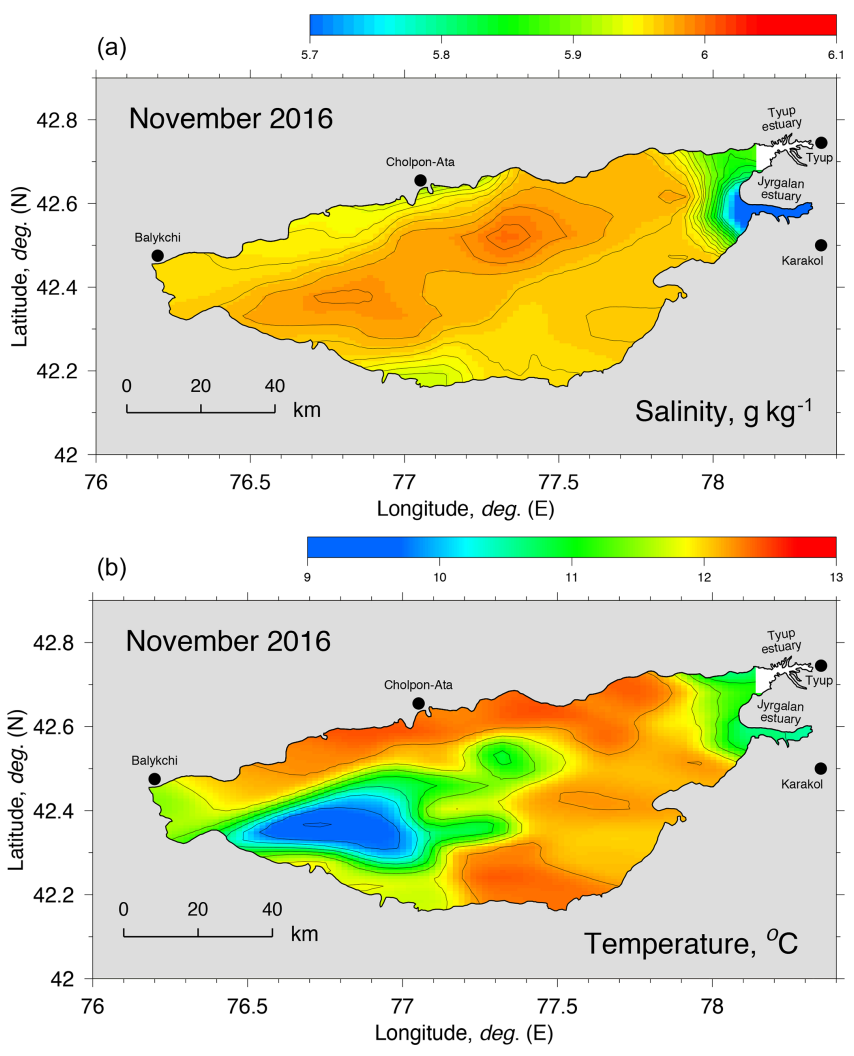

Figure 3. (a) Salinity and (b) temperature distributions at the lake surface in November 2016, based on pump-through CTD measurements.

\subsection{Horizontal thermohaline structure and its variability}

The salinity and temperature distributions at the surface derived from continuous pump-through CTD measurements of November 2016 are shown in Fig. 3. The salinity map is virtually the most detailed ever obtained for the Issyk-Kul. In fact, the horizontal variability of the salinity field is remarkably small - with the exception of the areas immediately adjacent to river mouths, the total salinity span over the entire lake does not exceed a mere few hundredths of a gram per kilogram (more precisely, about $0.04 \mathrm{~g} \mathrm{~kg}^{-1}$ ). This is indicative of intense mixing processes taking place in the lake.

However, the discharge from the Jyrgalan and Tyup rivers, bringing to the lake respectively 28 and $12 \mathrm{~m}^{3} \mathrm{~s}^{-1}$ of freshwater on long-term average (Romanovsky, 1991) does exhibit a distinct signature in salinity on the eastern shelf, forming a zone of a high-salinity gradient centered at about $78^{\circ} \mathrm{E}$. The haline structure in this area is depicted in Fig. 4a based on CTD stations shown by the green bullets in Fig. 1. As can be seen from Fig. $4 a$, the plume of relatively low salinity water associated with the Jyrgalan River runoff extends for over $20 \mathrm{~km}$ from the river inlet, mainly confined to the upper $20 \mathrm{~m}$ portion of the water column. This plume is also character- 


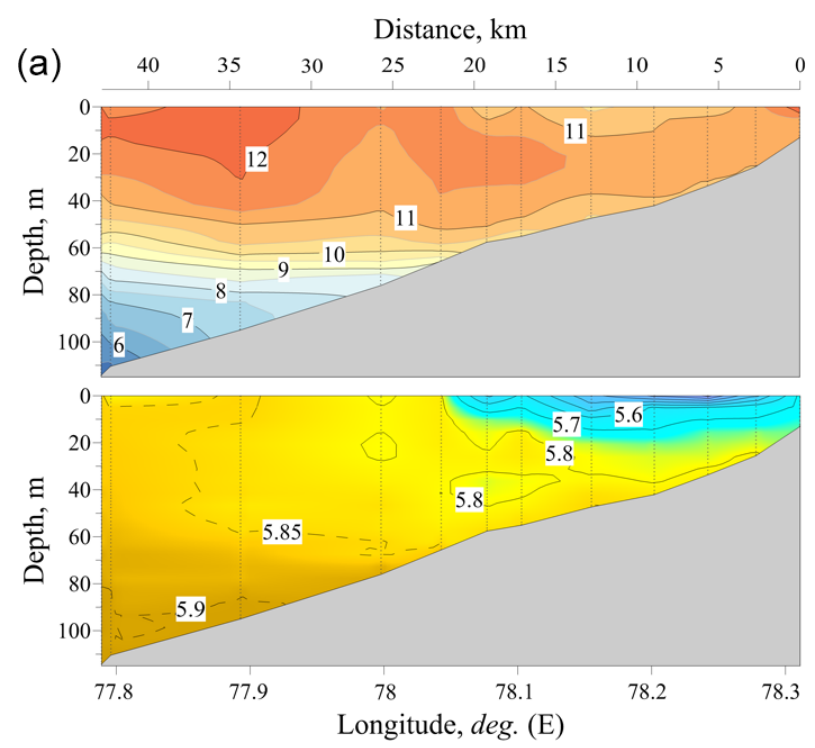

(b)

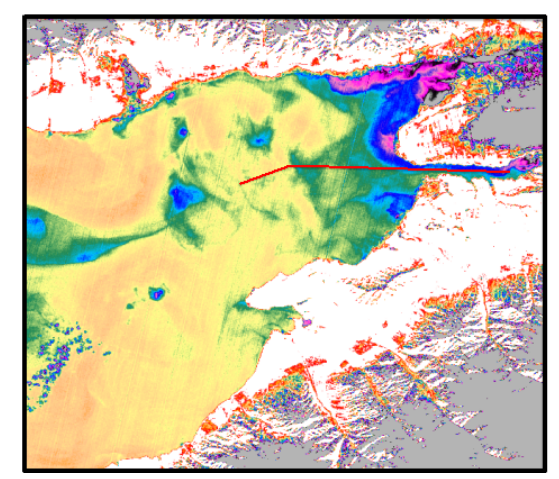

Figure 4. (a) Distribution of temperature $\left({ }^{\circ} \mathrm{C}\right.$, a) and salinity $\left(\mathrm{g} \mathrm{kg}^{-1}, \mathbf{b}\right)$ in a longitudinal section following the ancient bed of the Jyrgalan River on the eastern shelf (green bullets in Fig. 1) on 1-2 November 2016. (b) Landsat infrared satellite image at $60 \mathrm{~m}$ resolution obtained on the same day (courtesy of Alexei Kouraev, LEGOS, France). Red line corresponds to the section where the in situ measurements shown in Fig. 4a were taken.

ized by temperature that is lower than that of the surrounding waters by $1-2{ }^{\circ} \mathrm{C}$. However, some nuclei of low-temperature, low-salinity water are also evident in the bottom layer downslope of the main plume (see Sect. 3.4 for discussion). An infrared Landsat satellite image at $60 \mathrm{~m}$ resolution taken simultaneously with the in situ measurements reveals more details of the thermal structure at the surface (Fig. 4b). It can be seen that the coldest water is actually concentrated in a relatively narrow (1-4 km wide) stripe adjacent to land and extending from the Jyrgalan to the Tyup estuary.

Some near-coast regions of freshwater influence from smaller rivers are also evident at the southern and the northern extremities of the Issyk-Kul. Another notable feature is represented by slightly elevated salinity values in the central part of the lake, which is consistent with the traditional notion of the cyclonic basin-scale circulation resulting in a

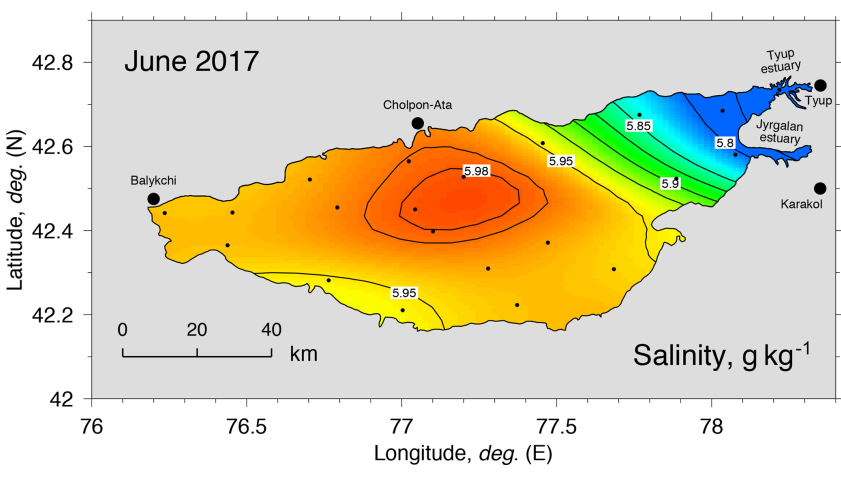

Figure 5. Salinity at lake surface in June 2017, based on data from hydrographic stations indicated by bullets.

dome-like structure in the central region where saltier waters below the thermocline come closer to the surface (e.g., Romanovsky, 1991). It is interesting that this area of higher salinity seems to split into a bimodal structure, with one maximum in the central northeastern and the other one in the central southwestern parts of the lake. This hints at two subbasin-scale cyclonic gyres superimposed on the general cyclonic circulation. Such sub-basin gyres are rather common for enclosed seas (e.g., Tuzhilkin, 2010) but have never been established for the Issyk-Kul.

For 2015 and 2017, the available salinity data are restricted to hydrographic stations, so the information about the horizontal distributions is less detailed. Generally, the interpolated surface salinity fields exhibited patterns similar to those characteristic of 2016, namely, very limited (about $0.06 \mathrm{~g} \mathrm{~kg}^{-1}$ ) range of spatial variability across the lake area (except in the region of freshwater influence on the eastern shelf) and slight but distinct salinity maximum in the central part of the lake. Figure 5 presents the surface salinity field in June 2017. We omit here a similar plot for June 2015 and instead show in Fig. 6 the differences in salinity between June 2017 and June 2015. Overall, the observed changes in surface salinity over the 2 years were small; they never exceeded a few hundredths of a gram per kilogram and essentially totaled zero on average in the area. Interestingly, salinity increased in the eastern part of the lake, which is more strongly affected by river discharge, but decreased in the western part. The maximum difference of slightly over $0.04 \mathrm{~g} \mathrm{~kg}^{-1}$ was observed in the southeastern sector, namely, the Pokrovsky Bay adjacent to the mouths of the Dzhooku and the Kichene-Kyzylsu rivers.

The interannual differences observed in the lake surface temperature were more significant than those in salinity. The temperature fields for June 2017 and June 2015 are shown in Fig. 7. All over the lake, the surface water temperature in June 2017 was warmer than that in June 2015. While amounting to about $0.9^{\circ} \mathrm{C}$ on average in the area, however, this misfit was distributed unevenly over the lake area, with maximum changes taking place near the southwestern coast (Fig. 7). 


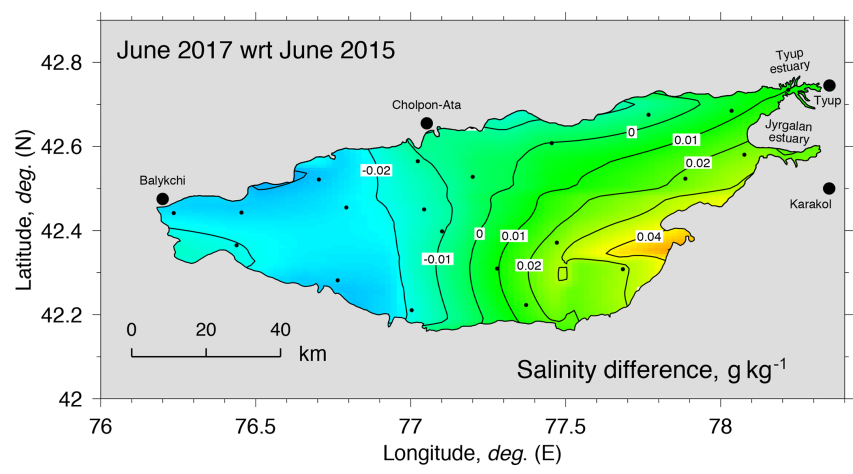

Figure 6. Difference of salinities at the surface observed in June 2017 and June 2015, based on data from hydrographic stations indicated by bullets.

Figure 8 shows ERA-Interim atmospheric reanalysis data (Dee et al., 2011), which indicate that from 15 June through 24 June (i.e., the period immediately preceding the measurements in the surveys) the daily mean near-surface air temperature in the study region was higher in 2017 than that in 2015 by $1-4{ }^{\circ} \mathrm{C}$ (Fig. 8a). It also follows from the same reanalysis data that the total heat flux received by the lake surface from the atmosphere (including solar irradiance) for this period in 2017 was significantly higher than that in 2015 (Fig. 8b). The differences of the net surface heat flux were mainly due to lake-air temperature contrasts and solar irradiance, given that the wind conditions were very similar (Fig. 8c). Therefore, the observed interannual differences in lake temperature are likely to reflect a response to different conditions of insolation and atmospheric forcing.

\subsection{Biogeochemical structure and its variability}

In this section, in order to evaluate the interdecadal variability, we repeatedly refer to the book by Kadyrov (1986). This monograph published in the Russian language presents hydrochemical data obtained by the author and his co-workers mainly during the period 1961-1985 (although some data reported by earlier researchers are also summarized in the book). Chemical parameters were determined in a certified laboratory of the Water Management Institute (city of Frunze, USSR) using standard methods and techniques adopted at the time. Nutrients and $\mathrm{pH}$ were analyzed colorimetrically, and oxygen through the Winkler titration.

The historical variability ranges shown along with our recent data in Figs. 9-11 were derived from the material presented in Kadyrov's book. They correspond to at least 535 samples for each parameter, collected mainly at 24 standard locations distributed over the open part of the lake.

\subsubsection{Oxygen}

During all our surveys, the entire water column down to the bottom was fully ventilated. The content of dissolved oxygen
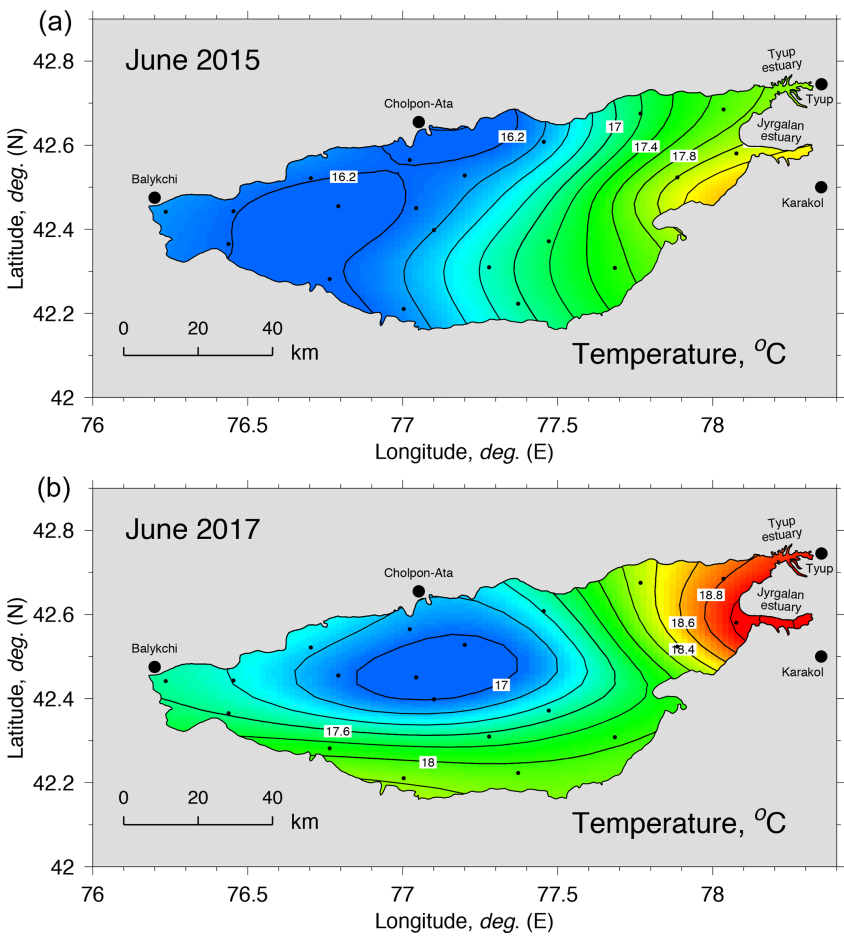

Figure 7. Distribution of lake surface temperature observed in June 2015 (a) and June 2017 (b), based on data from hydrographic stations indicated by bullets.

varied from 6.1 to $8.4 \mathrm{mLL}^{-1}$, and its saturation from $69 \%$ to $123 \%$ (Fig. 9a). Also shown in the figure is the respective range for oxygen saturation for the period 1961-1985, which was from $79 \%$ to $117 \%$ (Kadyrov, 1986). No significant change in oxygenation can be substantiated, although in the present both maximum and minimum values extend beyond the "old" range. The highest content of oxygen is usually situated at the upper edge of the thermocline. For surface water, the oxygen content ranged from 6.38 to $7.67 \mathrm{mLL}^{-1}$. The greatest interannual changes in the content of dissolved oxygen were observed at the upper layer, which is exposed to the influence of continental runoff and activity of the aquatic biota. Below $200 \mathrm{~m}$, the content of oxygen and its saturation manifested no significant interannual differences.

\subsubsection{Alkalinity and $\mathrm{pH}$}

Overall, during the three surveys, the total alkalinity ranged from 1.04 to $5.47 \mathrm{mgEq} \mathrm{L}^{-1}$ (Fig. 9b). However, low alkalinity values were confined exclusively to the areas adjacent to river mouths, while for the bulk of the lake waters the span of alkalinity values was between 5.37 and $5.44 \mathrm{mgEq} \mathrm{L}^{-1}$, with a mean value of $5.41 \mathrm{mgEqL}^{-1}$, which constitutes a noteworthy increase with respect to the values reported by Kadyrov (1986). Hereinafter, the data extracted from the book by Kadyrov (1986) refer to all depth levels below $200 \mathrm{~m}$. The mean pH was 8.68 , nearly the same as 8.71 in the 1980 s. The 

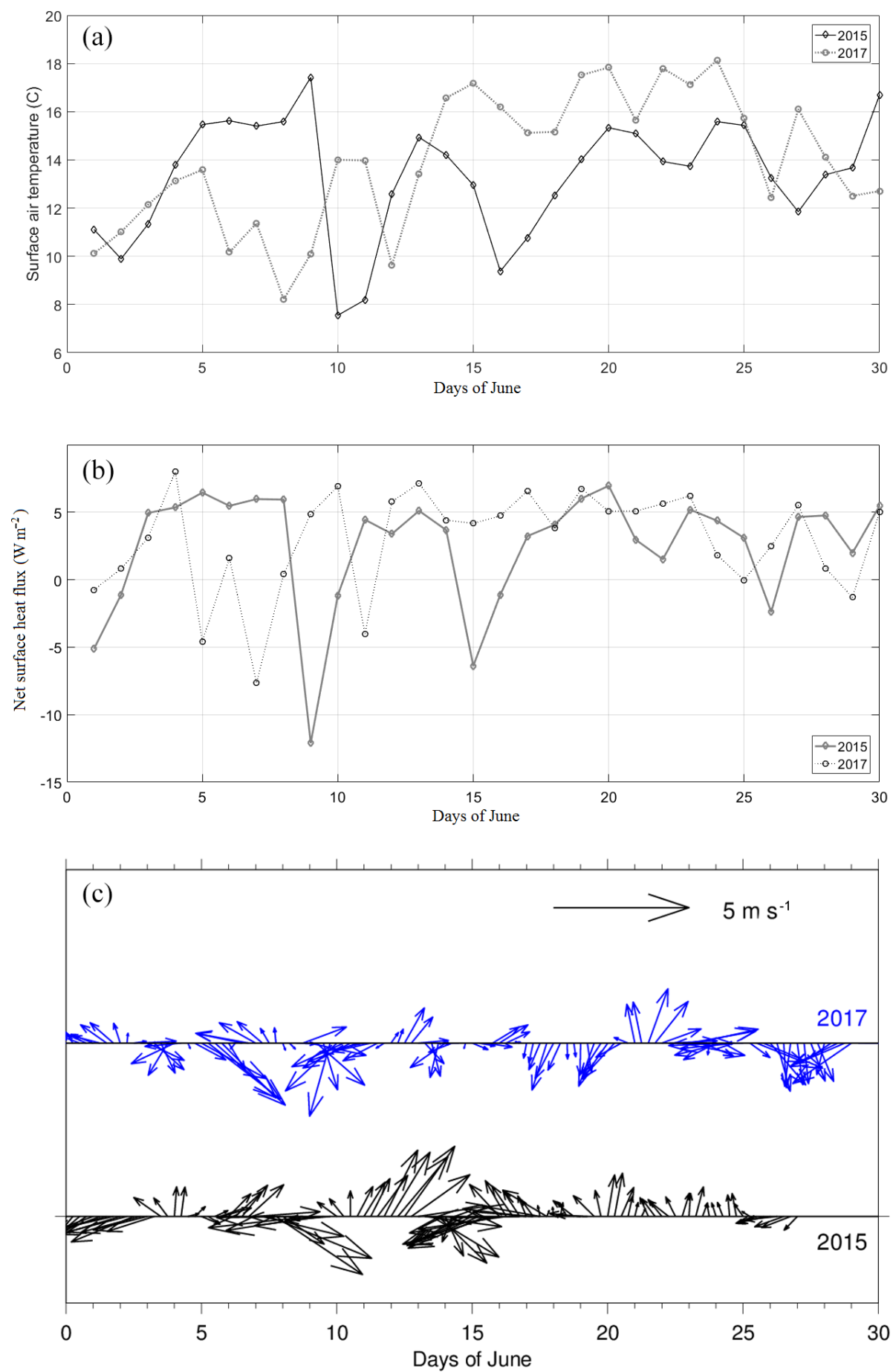

Figure 8. (a) Air temperature at $2 \mathrm{~m}$ height in June 2015 and June 2017 from ERA-Interim reanalysis. (b) Net surface heat flux in June 2015 and June 2017. Positive sign corresponds to gain of heat by the lake. (c) Wind speed vectors at $2 \mathrm{~m}$ height in June 2015 (black) and June 2017 (blue) from ERA-Interim reanalysis. The data correspond to the point $42^{\circ} 20^{\prime} \mathrm{N}, 77^{\circ} 30^{\prime} \mathrm{E}$ in the central part of the lake.

small change in the alkalinity and $\mathrm{pH}$ along the vertical, as well as there being practically no change from one survey to another, once again suggests that the entire water column in the lake mixes actively. In the central part of the lake, a slight increase in $\mathrm{pH}$ (by about 0.05 with respect to the average) and total alkalinity (by about $0.05 \mathrm{mgEq} \mathrm{L}{ }^{-1}$ with respect to the average) at the surface was evident in horizontal distributions (not shown here). Most likely, this feature observed in all 3 years, as well as the abovementioned salinity maximum 

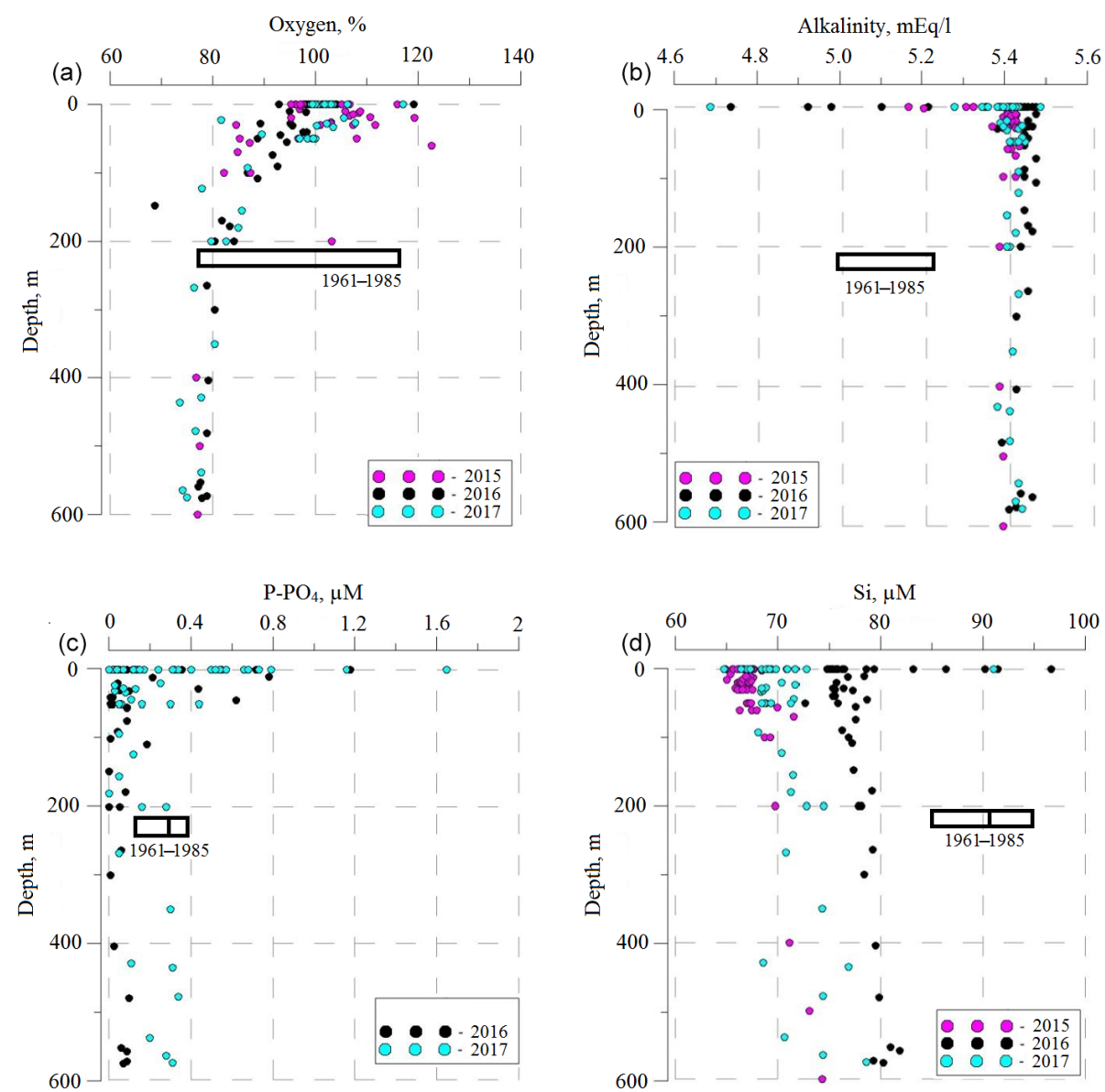

Figure 9. Vertical distributions of oxygen saturation (a), alkalinity (b), phosphates (c), and silicates (d) in different surveys. Black boxes indicate the typical range for waters below $200 \mathrm{~m}$ in 1961-1985 (Kadyrov, 1986), except for oxygen, where the box indicates the overall range. The vertical lines in the boxes show average values (where available).

in the central area of the lake, is associated with the rise of waters due to cyclonic basin-scale circulation.

\subsubsection{Phosphates}

The content of phosphates in the lake waters was determined only in 2016 and 2017. The concentration of phosphates varied from the analytical zero (i.e., below the detection limit by the method) to 1.16 . The maximum value was detected in the surface waters at the eastern extremity of the lake, most likely due to the influence of continental discharge from the Jyrgalan and Tyup rivers. Slightly elevated concentrations of phosphates were also observed in the central region, consistent with similar features in salinity, $\mathrm{pH}$, and alkalinity. All over the lake area, relatively high content of dissolved inorganic phosphorus was observed in the upper water layer down to about $50 \mathrm{~m}$ (Fig. 9c). This may be associated with the influx of phosphorus by runoff from the coast, including sewage in urban areas, and/or with the oxidation of organic matter formed during the period of active photosynthesis. It is interesting that in the bottom layer, where the organic ox- idation processes should take place, we did not observe any significant increase in the content of inorganic phosphorus or a noticeable decrease in dissolved oxygen and $\mathrm{pH}$. Again, this is suggestive of efficient mixing of the water column.

During the November survey of 2016, the phosphate concentration in the layer from $200 \mathrm{~m}$ to the bottom varied from an analytical zero to $0.1 \mu \mathrm{M}$, which is lower than the existing (although sparse) historical data for the decade of the 1980s, when the concentration typically ranged from 0.19 to $0.38 \mu \mathrm{M}$ below $200 \mathrm{~m}$ (Kadyrov, 1986). However, in June 2017, the phosphate content below the thermocline was significantly higher, totaling $0.4 \mu \mathrm{M}$ on average. Most likely, this was due to oxidation of organic matter coming from the upper active layer into the deep waters of the lake following plankton bloom (see below).

\subsubsection{Silicates}

The content of dissolved silicates in the lake water varied from 64.8 to $96.1 \mu \mathrm{M}$ (Fig. 9d). The maximum range of silicate content was observed in surface waters. Below $100 \mathrm{~m}$ 
depth, the average silicate content was about $79 \mu \mathrm{M}$, with a certain increase towards the bottom.

The silicates content profile observed in 2017 was close to that documented in 2015. In 2016, the silicate concentrations were higher by about $10 \%$ throughout the column. This may reflect seasonal changes, although a longer series of observations is needed to confirm it. However, the concentrations registered in all three surveys were notably lower than those reported by Kadyrov (1986), whose averages ranged from 86 to $95 \mu \mathrm{M}$.

The horizontal distributions of nutrients at the surface observed in all surveys generally looked alike and were characterized by distinct maxima on the eastern shelf in the areas adjacent to the Jyrgalan and Tyup estuaries, and by smaller concentrations rather uniformly distributed elsewhere. An example of silicate concentration is shown in Fig. 10. The position of the frontal zone separating the low- and highconcentration zones is nearly coincident with the salinity front seen in Fig. 3. The observed distributions indicate that the discharge from the Jyrgalan and the Tyup is the principal if not the only source of nutrients to the lake.

\subsubsection{Nitrates and nitrites}

The content of nitrates in the water of the lake varied from 1.2 to $16.1 \mu \mathrm{M}$, and that of nitrites from analytical zero to $0.54 \mu \mathrm{M}$ (Fig. 11), with the largest variability observed in the surface layer. Below the thermocline, nitrate concentration ranged from 1.2 to $12.9 \mu \mathrm{M}$. The respective span for nitrites was from 0 to $0.23 \mu \mathrm{M}$.

The values of nitrate content obtained during different surveys diverged quite significantly. In 2017, the concentrations were lower than those in 2015 and 2016, virtually throughout the column. In addition, in 2015 and 2016, a moderate increase of nitrate content towards the bottom was manifested in the layers below $100 \mathrm{~m}$, while in 2017 this pattern was no longer there. As for nitrites, in 2015 and 2016, their concentrations below $100 \mathrm{~m}$ depth were very low (especially in 2016, when they were close to analytical zero) and nearly uniform. In 2017, however, the content of nitrates in the deep waters of the lake increased to $0.1 \mu \mathrm{M}$. In all three surveys, the highest content of nitrites was observed at the "confluence" of the Tyup and Jyrgalan estuaries. In 2017, high content was observed not only in the eastern but also in the central part of the lake.

According to Kadyrov (1986), in the 1980s, the concentration of nitrates ranged from 2.6 to $16 \mu \mathrm{M}$, and that of nitrites varied between 0.05 and $0.15 \mu \mathrm{M}$. Hence, no significant change since then is evident.

\subsubsection{Chlorophyll $a$ and total suspended matter}

The measurements of chlorophyll $a$ concentration and the content of the total suspended matter (hereinafter TSM) in the surface layer are summarized in Fig. 12. The inset table in

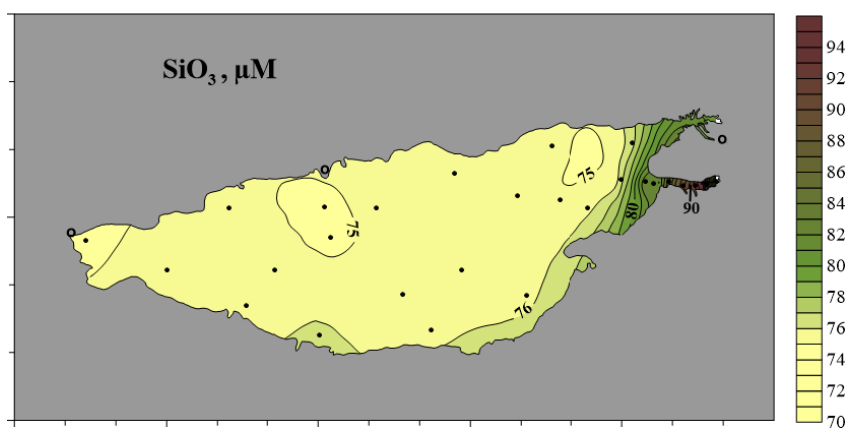

Figure 10. Concentration of silicates $(\mu \mathrm{M})$ at the lake surface in November of 2016.

the upper part of the figure refers to the lidar measurements encompassing a total of 169166 data points distributed all over the lake along the ship's tracks, while the bullets in the plot depict data from water samples collected at the stations. Also shown in Fig. 12 is the CCI, showing the age or the life stage of the plankton; see Data section above for details.

The lidar data indicate that while the maximum concentrations of TSM are observed in the eastern part of the Issyk$\mathrm{Kul}$, as may have been expected because this part of the lake is more strongly exposed to river discharge, the chlorophyll concentrations demonstrate the opposite pattern, with maximum values pertaining to the western and especially the northwestern regions. One striking feature evident in both the lidar and the in situ data is the fact that overall chlorophyll concentrations in June 2017 were much higher than those in June 2015 by a factor of 5 on the average, and in the southeastern part of the lake most exposed to river discharge even by a factor of 7.3. This somewhat surprising difference cannot be explained by seasonal cycling, as the two surveys took place almost on the same days of year. However, the pigment index may give some insights into this matter, showing that at the time of the observations in 2015 the planktonic communities were represented mainly by "old", post-bloom plankton, while those in 2017 (as well as in November of 2016) were represented mainly by "young" plankton. This indicates that the spring bloom of 2015 occurred earlier than that of 2017, and timing of plankton blooms in the Issyk-Kul is significantly variable from year to year, perhaps depending on weather conditions and supply of nutrients by rivers. Differences that are even more significant are documented in TSM, whose average concentration in June 2017 exceeded that in June 2015 by a factor of 10.1. On the one hand, this indicates that the suspended matter in the Issyk-Kul is tightly connected with planktonic communities, and at least a part of the TSM is of biogenic origin. On the other hand, this may point to elevated river discharge bringing both TSM and nutrients immediately before and during the plankton bloom.

Vertical and longitudinal distribution of chlorophyll $a$ along the Jyrgalan canyon based on the sampling conducted on 1 November 2016 (green bullets in Fig. 1) is shown in 
(a)

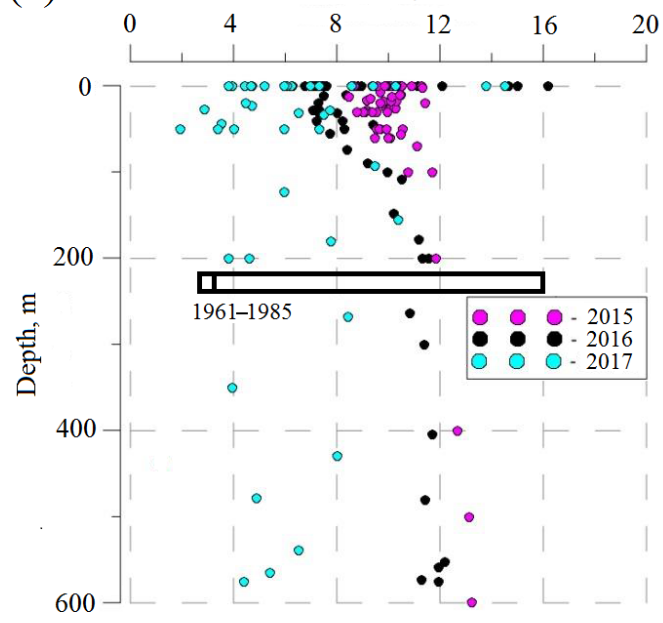

(b)

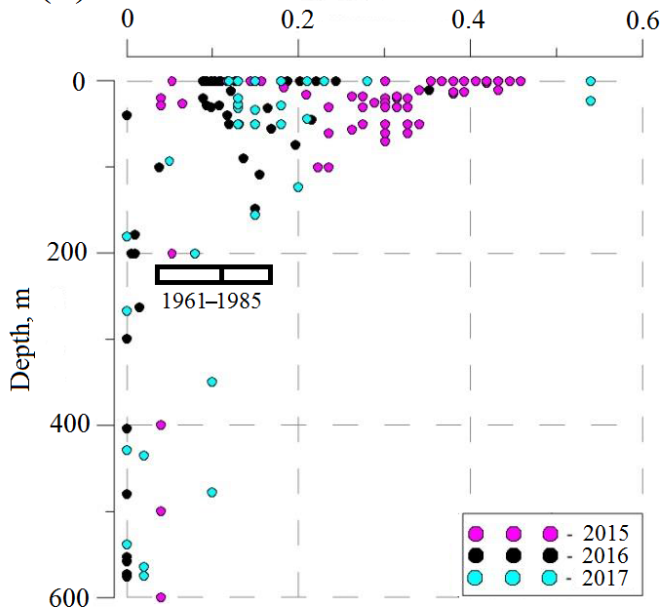

Figure 11. Vertical distributions of concentration of nitrates (a) and nitrites (b) during the surveys of 2015, 2016, and 2017. Black box indicates the typical range for waters below $200 \mathrm{~m}$ in 1961-1985 (Kadyrov, 1986). The vertical lines in the boxes show average values.

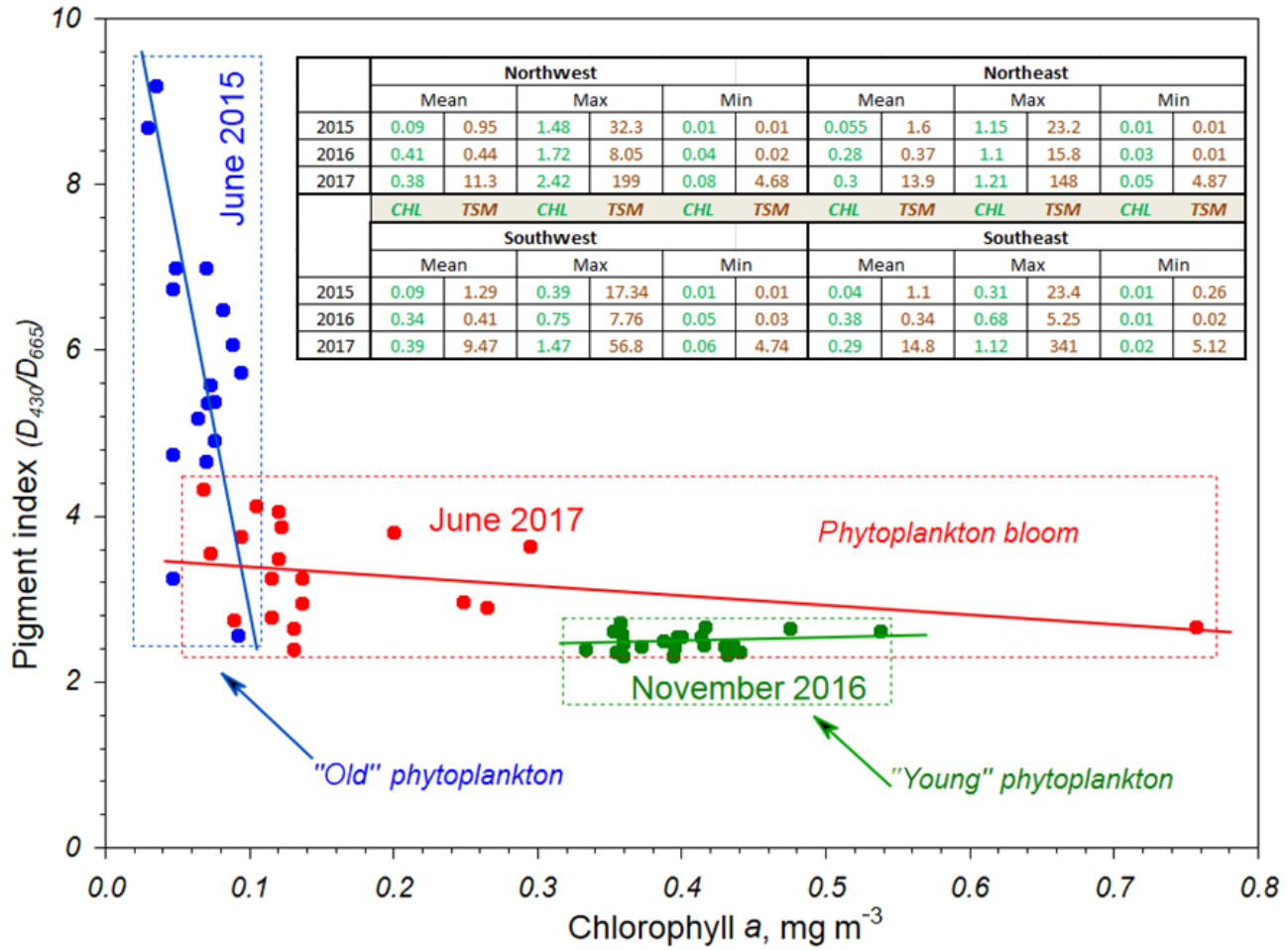

Figure 12. Chlorophyll- $a$ concentration and CCI pigment index for June 2015 (blue bullets), November 2016 (green bullets), and June 2017 (red bullets). The straight lines represent linear regressions. The concentrations of chlorophyll ( $\mathrm{mg} \mathrm{m}^{-3}$, "CHL" columns) and total suspended matter ( $\mathrm{g} \mathrm{m}^{-3}$, "TSM" columns) are also exhibited in the inset table as the minimum and the maximum values and averages in four parts of the lake, delimited here by the $42.45^{\circ} \mathrm{N}$ parallel and the $77.4^{\circ} \mathrm{E}$ meridian. 


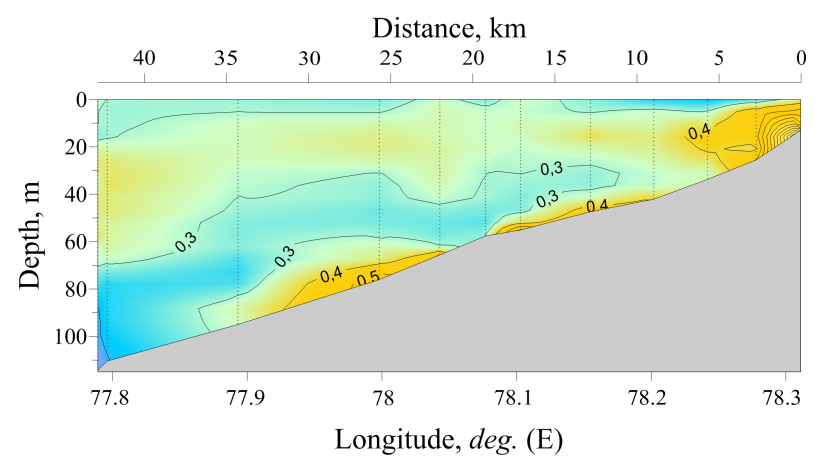

Figure 13. Vertical distribution of chlorophyll $a$ concentration $\left(\mathrm{mg} \mathrm{m}^{-3}\right)$ in a longitudinal section following the ancient bed of the Jyrgalan River on the eastern shelf on 1 November 2016.

Fig. 13. The maximum concentration is observed near the shore in proximity of the river mouth. To the west of the estuary, the vertical structure of chlorophyll exhibits two maxima, one at the upper boundary of the thermocline at a depth of about $20 \mathrm{~m}$ and the other one near the bottom. The upper maximum of plankton activity just below the mixed layer is characteristic for the entire lake and generally coincides with the maximum concentration of nutrients. The near-bottom maximum is likely related to downslope advection of chlorophyll-rich, cold waters from the eastern shelf during cooling period as discussed in the next subsection.

\subsection{Seasonal cooling on eastern shelf and its possible implications}

The data from the moored thermistor chains deployed on 1 November 2016 and recovered on 27 March 2017 gave some insights into details of how winter cooling progressed on the eastern shelf of the lake. As mentioned above, two moorings were installed into the paleo-beds of the Jyrgalan and Tyup rivers, and one on the shelf between them. Figure 14 shows bathymetric profile across the Jyrgalan and Tyup canyons at $77.9^{\circ} \mathrm{E}$ obtained by echo soundings on 25 June 2015. The thermistor chains were deployed on a similar terrain east of this section.

The complete set of data from the thermistor chains is exhibited in Fig. 15, demonstrating gradual general cooling from about $13^{\circ} \mathrm{C}$ in early November to about $3{ }^{\circ} \mathrm{C}$ in late February-early March, followed by the onset of spring warming in mid-March. Also shown in the figure is the surface air temperature from the ERA-Interim reanalysis. Figure 16 zooms in on the Jyrgalan canyon record for November 2016. Both figures exhibit a number of distinct cooling events. Some of these episodes originate from the surface and then propagate downwards, presumably due to convective mixing, such as the events of late December following abrupt decrease of the air temperature (Fig. 15) or the events of 7, 17, and 22 November clearly seen in Fig. 16. In contrast, other events $(5,14,26$ November) appear in the bottom

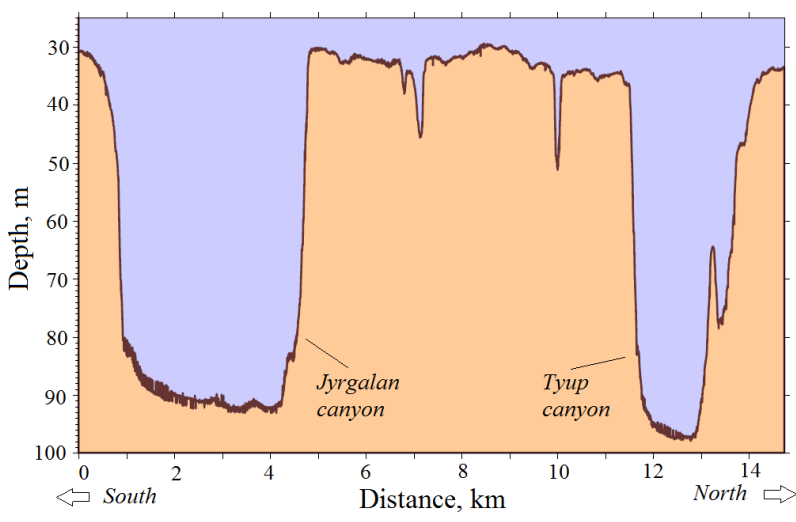

Figure 14. Bathymetric profile of a meridional section across the Jyrgalan and Tyup canyons at $77.9^{\circ} \mathrm{E}$ obtained by echo soundings on 25 June 2015.

layer with no sign of equally cold water in the upper parts of the column and, therefore, can only be attributed to lateral advection.

A closer look at the temperature records reveals that the general cooling was mediated by a large number of relatively short individual events. To investigate their statistics and evaluate the relative roles of advective and convective cooling, we performed the following analysis.

Hereinafter, we refer to the term "bottom cooling event" to identify the situation where temperature at the bottom sensor decreased continuously during a series of sequential readings. Because the sampling rate of the sensors was set to $1 \mathrm{~min}$, only events lasting 2 min or more were taken into account. Furthermore, the event was considered "convective" if, at the beginning of it, temperature at the bottom sensor was higher than that at the next sensor of the chain counting from the bottom, and "advective" otherwise. Because the observed temperatures in all cases were above the temperature of maximum density (TMD), which is about $2.75^{\circ} \mathrm{C}$ for Issyk-Kul water (Romanovsky, 1991), and salinity stratification in the bottom layer was virtually negligible, the situation of temperature inversion implies convective instability. On the other hand, the absence of such inversion means that the observed decrease of temperature with time cannot be explained by vertical heat exchanges and hence must be attributed to lateral advection.

The entire set of data recorded by three thermistor chains has been analyzed accordingly. The resulting statistics are depicted in Table 1. The total duration of cooling at the bottom over the measurements period was different for the three locations and ranged from $60780 \mathrm{~min}$ (42.2 days) for the Jyrgalan canyon to 104981 min (72.9 days) for the Tyup canyon. The total duration of bottom cooling at the reference mooring station situated on the flat shelf between the canyons was 95783 min (66.5 days), which is higher than that for the Tyup canyon and only slightly lower than that for the Jyrgalan canyon. However, while on the shelf outside 


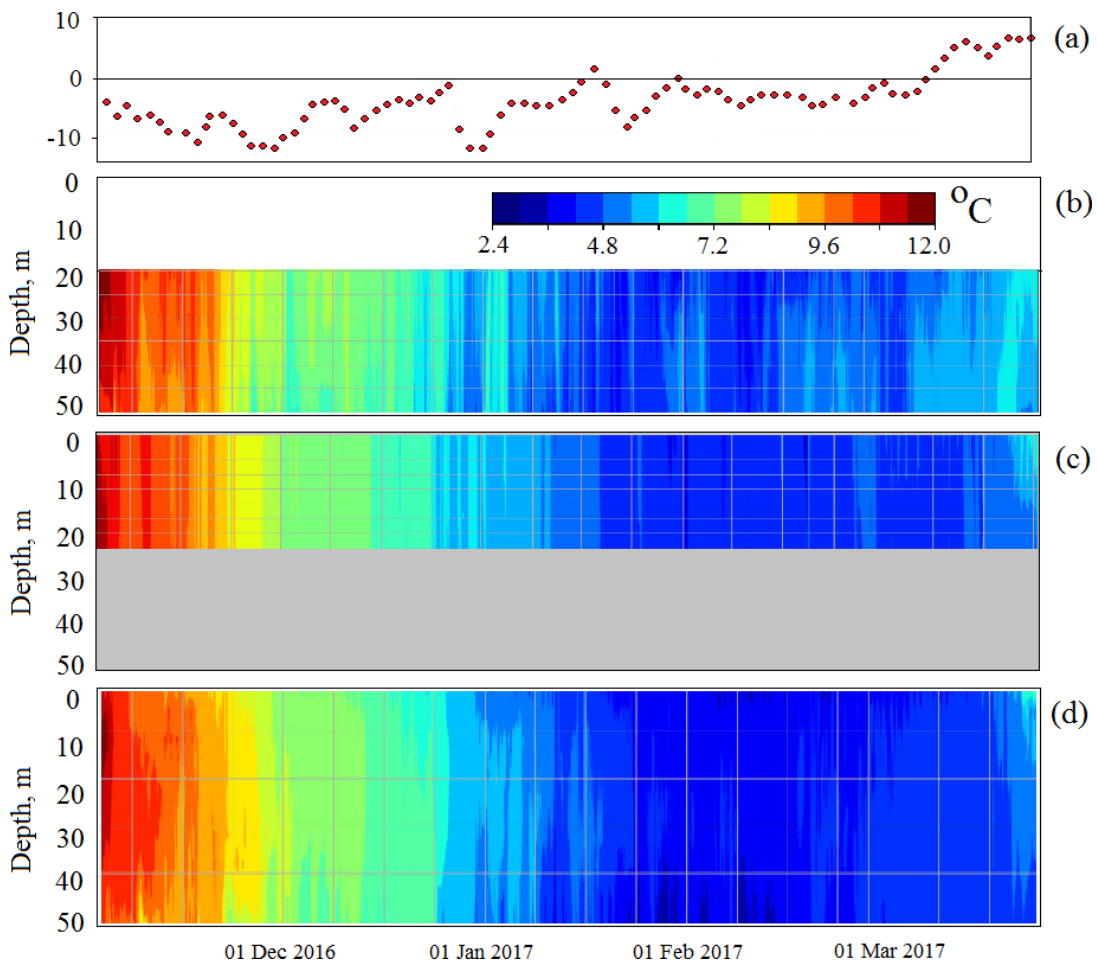

Figure 15. (a) Air temperature $\left({ }^{\circ} \mathrm{C}\right)$ at $2 \mathrm{~m}$ height from ERA-Interim reanalysis data corresponding to the point $42^{\circ} 20^{\prime} \mathrm{N}, 77^{\circ} 30^{\prime} \mathrm{E}$ in the central part of the lake. (b) Water temperature record from thermistor chain in the Tyup canyon. (c) Water temperature record from thermistor chain on the shelf between the Tyup and the Jyrgalan canyons. (d) Water temperature record from thermistor chain in the Jyrgalan canyon.

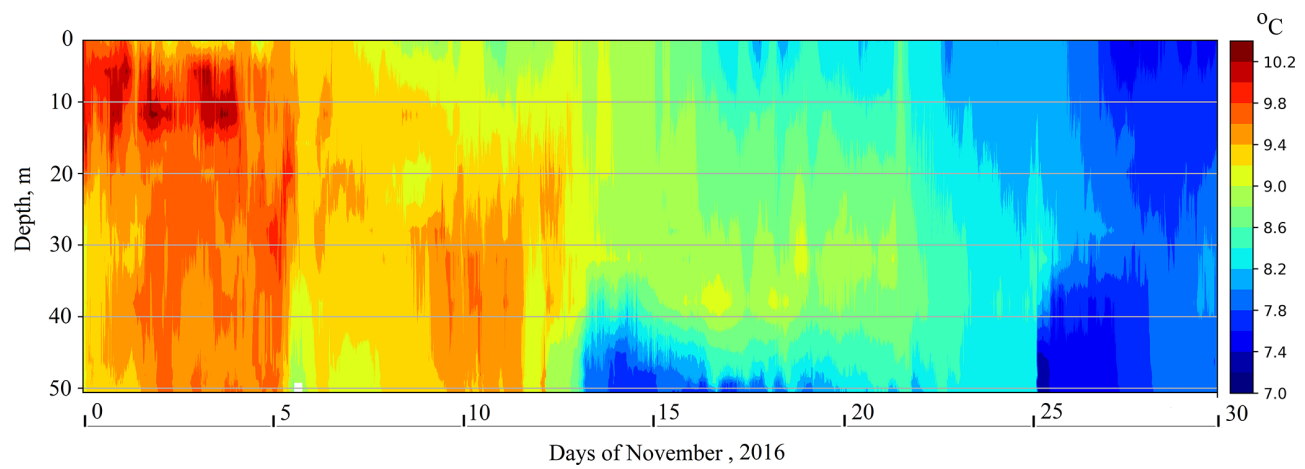

Figure 16. Water temperature variability in the Jyrgalan canyon in November 2016, as obtained from thermistor chain data.

the canyons the convective and advective mechanisms were responsible for an approximately equal number of cooling events, within the canyons the advective mechanism clearly prevailed, accounting for about two-thirds of all bottom cooling events in the Tyup canyon and almost $90 \%$ of bottom cooling events in the Jyrgalan canyon. It also appears that the individual advective events within the canyons tended to last longer than those on the flat shelf (maximum duration of $41 \mathrm{~min}$ versus $19 \mathrm{~min}$ ) and produce a stronger temperature drop (up to $1.36^{\circ} \mathrm{C}$ versus $0.29^{\circ} \mathrm{C}$; considering the maximum values, the average figures are much smaller but seem to have a similar relation). Thus, in this sense, the newly ob- tained data support the hypothesis put forward by Peeters et al. (2003) that during the cooling period the paleo-riverbeds on the eastern shelf of the Issyk-Kul lake may serve as "pathways" guiding relatively cold and dense shelf water formed as a result of differential cooling towards the deep basin. The signature of this water is also seen in the distribution of chlorophyll $a$ concentration along the Jyrgalan canyon recorded on 1 November 2016, as presented in Fig. 13. The vertical profile shown there is characterized by two maxima of chlorophyll. The first, centered at depths of $20-30 \mathrm{~m}$ just below the upper mixed layer, has been commonly observed in the Issyk-Kul lake (Kadyrov, 1986). But the stronger max- 
Table 1. Basic statistics of observed cooling events.

\begin{tabular}{|c|c|c|c|c|c|c|c|}
\hline \multirow[t]{2}{*}{ Site } & \multirow[t]{2}{*}{$\begin{array}{l}\text { Total duration of } \\
\text { cooling, min/days }\end{array}$} & \multicolumn{2}{|c|}{$\begin{array}{l}\text { Number of } \\
\text { cooling events }\end{array}$} & \multicolumn{2}{|c|}{$\begin{array}{l}\text { Duration of cooling event, } \\
\text { min (maximum/mean) }\end{array}$} & \multicolumn{2}{|c|}{$\begin{array}{l}\Delta T \text { over event, }{ }^{\circ} \mathrm{C} \\
\text { (maximum/mean) }\end{array}$} \\
\hline & & Convective & Advective & Convective & Advective & Convective & Advective \\
\hline $\begin{array}{l}\text { 1. Jyrgalan canyon, } \\
51 \mathrm{~m} \text { depth }\end{array}$ & $60780 / 42.2$ & $1442,10.7 \%$ & $11960,89.3 \%$ & $15 / 3.1$ & $41 / 3.5$ & $0.59 / 0.01$ & $0.56 / 0.01$ \\
\hline $\begin{array}{l}\text { 2. Tyup canyon, } \\
50 \mathrm{~m} \text { depth }\end{array}$ & $104981 / 72.9$ & $8743,35.2 \%$ & $16086,64.8 \%$ & $28 / 3.1$ & $32 / 3.3$ & $0.79 / 0.02$ & $1.36 / 0.03$ \\
\hline $\begin{array}{l}\text { 3. Shelf between the } \\
\text { canyons, } 23 \mathrm{~m} \text { depth }\end{array}$ & $95783 / 66.5$ & $13188,54.2 \%$ & $11164,45.8 \%$ & $24 / 3.0$ & $19 / 3.1$ & $0.25 / 0.01$ & $0.29 / 0.01$ \\
\hline
\end{tabular}

imum at the bottom, beyond the euphotic layer where plankton normally develops, is likely to originate from surface water in the shallow parts of the shelf sinking to the bottom because of cooling and propagating westward down the slope within the canyon.

Based on these findings and assuming that the advection of cold shelf waters is a dominant mechanism controlling winter cooling within the submerged riverbeds, we now can approximately estimate the scale $v$ of the downslope velocity mediating this process. Indeed, in this case,

$$
\frac{\partial T}{\partial t} \sim v \frac{\partial T}{\partial x}
$$

where $T$ is the temperature of water in the canyon, $t$ is time, and $x$ is the coordinate along the canyon. The values of $\frac{\partial T}{\partial t}$ and $\frac{\partial T}{\partial x}$ for the conditions of November 2016 can be estimated from the data presented above in Figs. 4, 15, and 16 as $\frac{\partial T}{\partial t} \sim 2{ }^{\circ} \mathrm{C}_{\text {month }}-1 \sim 10^{-6}{ }^{\circ} \mathrm{C} \mathrm{s}^{-1}$, and $\frac{\partial T}{\partial x} \sim 1{ }^{\circ} \mathrm{C} / 10 \mathrm{~km} \sim$ $10^{-4}{ }^{\circ} \mathrm{C} \mathrm{m}^{-1}$. It follows then from the equation above that $v \sim 10^{-2} \mathrm{~m} \mathrm{~s}^{-1}$. Furthermore, given that the cross-sectional area of the Jyrgalan canyon is on the order of $10^{5} \mathrm{~m}^{2}$ (Fig. 14), this suggests that the total volume of water that passed through the canyon towards the deep part of the lake during 1 month of autumn cooling is on the order of $0.1 \mathrm{~km}^{3}$.

Admixture of the cold and relatively fresh shelf water, originally at average salinity of about $5.8 \mathrm{~g} \mathrm{~kg}^{-1}$ (Fig. 4), which moves downslope and settles at its isopycnal level in the bulk of the water column, to nearly $6 \mathrm{~g} \mathrm{~kg}^{-1}$ salinity ambient water, must result in a certain decrease of salinity in the affected part of the column. If we assume that the inflowing water is distributed horizontally over the entire area of the deep floor of the lake $\left(\sim 4 \times 10^{9} \mathrm{~m}^{2}\right)$ and vertically throughout the column from the bottom to the depth of the intermediate salinity maximum discussed above, i.e., a layer over $\sim 500 \mathrm{~m}$ thick, a simple balance estimate demonstrates that the resulting salinity drop in the lower portion of the water column should be on the order of $10^{-3} \mathrm{~g} \mathrm{~kg}^{-1}$. This effect should be amplified by the presence of the inflow not only through the Jyrgalan canyon but also through the Tyup canyon and, possibly, flat shelf in a similar process; furthermore, the duration of the cooling period is al- most 4 months (Fig. 15). Therefore, one should expect that the salinity drop in the bottom part of the column due to admixture of cold shelf waters propagating through the Tyup and Jyrgalan canyons would be on the order of a few thousandths of a degree Celsius - which is, indeed, evident in the observations.

In summary, the suggested mechanism of deep-water renewal can be schematized as follows. With the onset of cooling in autumn, the strongest temperature drop is observed above the ample shoals in the eastern littoral region. The surface water in this area is also slightly, by a few tenths of a gram per kilogram, less saline than that in the bulk of the lake because of the freshwater discharge from the Jyrgalan and Tyup river estuaries. Nevertheless, cooling accompanied by density increase eventually results in convection and descent of water to the bottom layer on the eastern shelf, where they accumulate in the canyons formed by the ancient Jyrgalan and Tyup rivers. Flowing down the slope, these cold and dense but ventilated and relatively fresh waters are conveyed by the canyons to the shelf break and then sink further to their isopycnal levels in the abyss of the lake, thus producing the salinity maximum in the intermediate layers. The magnitude of the observed maximum seems to be consistent with this concept. The sinking shelf waters from the area of the Jyrgalan and Tyup estuaries are also rich in nutrients (see Fig. 10), so the mechanism discussed above may also contribute to biological productivity in the open part of the lake.

Hence, our newly obtained data reveal previously unknown details on winter temperatures in the eastern littoral region and suggest a connection of the deep-water renewal to horizontal salinity gradients in the Issyk-Kul. The lowest water temperatures observed in February near the lake bottom were in the range $2.5-3.0^{\circ} \mathrm{C}$, which falls near the range of the TMD for salinities found in Issyk-Kul. According to Romanovsky (1991), the TMD for the Issyk-Kul is $2.75^{\circ} \mathrm{C}$. At the outer edge of the cold nearshore areas, a frontal zone of "thermal bar" (e.g., Zilitinkevich et al., 1992) forms in many lakes, dividing water masses at temperatures above and below the TMD and characterized by strong downward convective flows. Indirect evidence of such flows in 
the Issyk-Kul can be found in the transient appearance of cold waters with temperatures close to the TMD at the lake bottom with warmer waters above (cold tongues at the lake bottom in February, Fig. 15d). In contrast to large freshwater lakes (Malm et al., 1993; Shimaraev et al., 1993; Ullman et al., 1998), in the Issyk-Kul the movement of the thermal bar towards the center of the lake will be restricted by the background lateral salinity gradients formed by freshwater inflows. However, the same salinity gradients together with the bottom slope will ensure volume contraction by mixing of the colder and fresher waters sinking into the warmer and saltier deep pelagial, resulting in the prominent cabbeling effect (Fedorov, 1981; McDougall, 1987). By this, the vertical convective flow formed within the thermal bar will follow the bottom slope towards the warmer lake center with positive vertical acceleration due to the dependence of the thermal expansion coefficient on temperature. This suggested mechanism of deep-water renewal differs from that reported in deep freshwater lakes, in particular, Lake Baikal (Killworth et al., 1996; Schmid et al., 2008), where downward vertical acceleration is created by the effect of thermobaricity (dependence of the thermal expansion coefficient on pressure). Still, the latter mechanism cannot be a priori assumed negligible in the ventilation of Issyk-Kul waters: Killworth (1977) argued that thermobaricity is even more important than cabbeling for deep water formation due to downslope cold freshwater flows, since it provides a faster increase of density with depth of fresher waters. In this sense, the Issyk-Kul may be illustrative of a number of physical mechanisms crucial for formation of deep water masses in the ocean, and it thus represents a natural "intermediate-scale" laboratory for investigating the cabbeling and thermobaricity effects on deep circulation.

\section{Conclusions}

As one of the world's largest and deepest lakes, the lake Issyk-Kul reflects the ongoing climate change trends and, reciprocally, exercises influence on climate, at least at regional scales. It is, therefore, important to be aware of the variability of the lake. The physical and chemical regimes of the Issyk-Kul were monitored on a regular basis during the Soviet era, although the information collected then was restricted to measurement techniques and equipment available at the time. For this reason, details of the structure and variability of salinity fields were poorly known. The amount of data obtained from the lake reduced greatly in the early 1990s, with only a few observational studies conducted since then. The aim of the present paper was to present new in situ data collected in three campaigns of 2015-2017, complemented by long-term deployments of moored thermistor chains.

The newly obtained data indicate that significant interdecadal warming of deep waters of the lake reported by Romanovsky et al. (2013) as almost $0.5^{\circ} \mathrm{C}$ for the period $1983-$
2003 is apparently no longer there, as the present-day temperature at $500 \mathrm{~m}$ depth is exactly same as it was in 2003 (namely, about $4.44^{\circ} \mathrm{C}$ ). However, in deep waters, there did exist a positive trend of salinity, which has increased by about $0.05 \mathrm{~g} \mathrm{~kg}^{-1}$ since 1984 , and about $0.02 \mathrm{~g} \mathrm{~kg}^{-1}$ since 2001 . Of course, it should be kept in mind that relatively rare measurements during the last few decades may not properly resolve some features of the interannual and interdecadal variability.

A pump-through CTD system and use of an empirical formula for converting CTD data to true salinity allowed highresolution salinity maps to be obtained with some features not resolved in previous measurements, such as a bimodal structure of the elevated salinity pattern in the central part of the lake, suggesting sub-basin-scale cyclonic gyres. Generally, the Issyk-Kul's salinity is amazingly close to constant, even in the surface layer exposed to river discharge. In fact, all of its horizontal variability over the entire lake area (except the river mouths) observed during the cruises of 2015 , 2016, and 2017 fitted into the interval of about $0.3 \mathrm{~g} \mathrm{~kg}^{-1}$, vertical variability was a mere $0.03 \mathrm{~g} \mathrm{~kg}^{-1}$, and the maximum temporal variability at fixed points at the interannual scale was only $0.04 \mathrm{~g} \mathrm{~kg}^{-1}$. This conservative behavior of salinity is unusual for inland water bodies and points to very efficient horizontal and vertical mixing. However, we did observe some slight redistributions of salinity fields from one year to another.

In contrast to the salinity, the temperature of the surface layer is subject to significant interannual variability controlled by atmospheric forcing conditions. This leads also to changes in timing of phytoplankton blooming in early summer, as expressed in the concentration of chlorophyll $a$.

The new data revealed no significant long-term changes in nutrients and other hydrochemical constituents, except for silicates, whose present-day concentrations throughout the water column are notably lower than those reported for the decades of the 1970s and 1980s, and alkalinity, which appears to have increased by about $0.2 \mathrm{mEq} \mathrm{L}^{-1}$.

Finally, we investigated in detail the development of seasonal cooling on the eastern shelf and the role of the paleoriverbeds in this process. Generally, cooling of the bottom layer occurred through a large number of individual cooling events, some of which originated from convective mixing from above, and others were due to lateral advection along the slope. The measurements demonstrated that, while on the flat shelf outside the river canyons the advective and convective cooling events were equally significant, the canyons themselves were dominated by advection, resulting in more efficient cooling. We can conclude, therefore, that the newly obtained data implicitly support the hypothesis by Peeters et al. (2003) that advection through the paleo-riverbeds following differential cooling on the eastern shelf plays an important role in modulating vertical structure in the deep part of the lake.

In this respect, we emphasize as an important finding of this study the intermediate salinity maximum observed below 
the thermocline, from where the salinity slightly decreased to the bottom. Its depth varied from year to year between 70 and $125 \mathrm{~m}$. This maximum is so weak $\left(0.004-0.009 \mathrm{~g} \mathrm{~kg}^{-1}\right)$ that it could not possibly have been detected using the techniques of the Soviet era, so it was never reported at that time. However, the intermediate salinity maximum seems to be a robust and persistent feature. Noteworthily, the opposite signs of temperature and salinity contributions to the density gradients beneath the salinity maximum suggest potential development of double-diffusive convection, which, at salinity decreasing with depth, should take the form of salt fingers (Schmitt, 1994) and may additionally contribute to the vertical mixing at water depths below $\sim 100 \mathrm{~m}$. The dynamical origins of the intermediate salinity maximum are likely to be related to the intrusion of lower-salinity, lower-temperature water from the eastern littoral during the differential cooling period. The observed salinity drop seems to be consistent with the volume of such intrusion estimated independently from thermistor chain measurements.

Data availability. The ERA-Interim reanalysis data used here are available after registration at https://www.ecmwf.int/en/forecasts/ datasets/archive-datasets/reanalysis-datasets/era-interim (ECMWF, 2018). The in situ data are available at the author's website: https://land.ocean.ru/en/data-for-downloads (Shirshov Institute of Oceanology, 2018).

Author contributions. PZ served as a principal investigator of this research at all its stages. He wrote the text of the paper. AI and GK participated in collection and analyses of hydrographic data. VK was responsible for meteorological data and atmospheric reanalyses used. VP and BK collected and analyzed the lidar and in situ data on chlorophyll and suspended matter. PM co-ordinated water sampling and chemical analyses. NRK conducted high-resolution bathymetry mapping of the area where the moorings were deployed. SA and KZ were involved in collection and processing of in situ data. They also served as local organizers during the field campaigns. All authors participated personally in the field work.

Competing interests. The authors declare that they have no conflict of interest.

Special issue statement. This article is part of the special issue "Modelling lakes in the climate system (GMD/HESS inter-journal SI)". It is not associated with a conference.

Acknowledgements. The field work of 2017 and the respective data analyses were funded by the Russian Foundation for Basic Research (grant no. 17-05-41043). The field campaigns of 2015-2016 were funded by the Russian Science Foundation (grant no. 14-50-00095). The measurements at the long-term mooring stations and the respective data analyses were supported by the Russian Ministry of Education and Science (agreement no. 14.W03.31-0006 and state assignment theme no. 0149-20180002). Georgiy B. Kirillin was supported by the German Research Foundation (DFG, projects KI 853-11/1, KI 853-11/2, KI 853-13/1)

Edited by: Miguel Potes

Reviewed by: two anonymous referees

\section{References}

Alamatov, A. and Mikkola, H.: Is biodiversity friendly fisheries management possible on Issyk-Kul lake in the Kyrgyz Republic?, AMBIO: A Journal of the Human Environment, 40, 479495, 2011.

Antal, T. K.: A study of primary production and phytoplankton characteristics using a submersible fluorescent probe, PhD Thesis, Moscow State University, Department of Biology, Moscow, Russia, 2000.

De Batist, M., Imbo, Y., Vermeesch, P., Klerkx, J., Giralt, S., Delvaux, D., Lignier, V., Beck, C., Kalugin, I., and Abdrakhmatov, K. E.: Bathymetry and sedimentary environments of Lake IssykKul, Kyrgyz Republic (Central Asia): A large, high-altitude, tectonic lake, in: Lake Issyk-Kul: Its Natural Environment, edited by: Klerkx, J. and Imanackunov, B., Dordrecht, NATO Science Series, Kluwer, 101-123, 2001.

Dee, D. P., Uppala, S. M., Simmons, A. J., Berrisford, P., Poli, P., Kobayashi, S., Andrae, U., Balmaseda, M. A., Balsamo, G., Bauer, P., Bechtold, P., Beljaars, A. C. M., van de Berg, L., Bidlot, J., Bormann, N., Delsol, C., Dragani, R., Fuentes, M., Geer, A. J., Haimberger, L., Healy, S. B., Hersbach, H., Hólm, E. V., Isaksen, L., Kållberg, P., Köhler, M., Matricardi, M., McNally, A. P., Monge-Sanz, B. M., Morcrette, J.-J., Park, B.-K., Peubey, C., de Rosnay, P., Tavolato, C., Thépaut, J.-N., and Vitart, F.: The ERA-Interim reanalysis: configuration and performance of the data assimilation system, Q. J. Roy. Meteor. Soc., 137, 553-597, https://doi.org/10.1002/qj.828, 2011.

ECMWF (European Centre for Medium-Range Weather Forecasts): ERA-Interim global atmospheric reanalysis, available at: https://www.ecmwf.int/en/forecasts/datasets/archive-datasets/ reanalysis-datasets/era-interim, last access: 4 December 2018.

Fedorov, K. N.: The role of compaction during mixing in the dynamics of oceanic fronts, Doklady Akademii Nauk SSSR, 261, 985-988, 1981.

Gebhardt, A. C., Naudts, L., De Mol, L., Klerkx, J., Abdrakhmatov, K., Sobel, E. R., and De Batist, M.: High-amplitude lake-level changes in tectonically active Lake Issyk-Kul (Kyrgyzstan) revealed by high-resolution seismic reflection data, Clim. Past, 13, 73-92, https://doi.org/10.5194/cp-13-73-2017, 2017.

Giralt, S., Klerkx, J., Riera, S., Julia, R., Lignier, V., Beck, C., De Batist, M., and Kalugin, I.: Recent paleoenvironmental evolution of Lake Issyk-Kul, in: Lake Issyk-Kul: Its Natural Environment, edited by: Klerkx, J. and Imanackunov, B., Dordrecht, NATO Science Series, Kluwer, 125-145, 2002.

Hofer, M., Peeters, F., Aeschbach-Hertig, W., Brennwald, M., Holocher, J., and Livingstone, D. M.: Rapid deep-water renewal in Lake Issyk-Kul (Kyrgyzstan) indicated by transient tracers, Limnol. Oceanogr., 47, 1210-1216, 2002. 
Kadyrov, V. K.: Hydrochemistry of Lake Issyk-Kul and its Catchment, Frunze, Ilim, 212 pp., 1986 (in Russian).

Killworth, P. D.: Mixing of the Weddell Sea continental slope, Deep-Sea Res., 24, 427-448, 1977.

Killworth, P. D., Carmack, E. C., Weiss, R. F., and Matear, R.: Modeling deep-water renewal in Lake Baikal, Limnol. Oceanogr., 41, 1521-1538, 1996.

Konovalov, B. V., Kravchishina, M. D., Belyaev, N. A., and Novigatsky, A. N.: Determination of the concentration of mineral particles and suspended organic substance based on their spectral absorption, Oceanology, 54, 5, 660-667, 2014.

Kulenbekov, Z. and Merkel, B. J.: Investigation of the natural uranium content in the Issyk-Kul lake, Kyrgyzstan, Freiberg Online Geology, 33, 3-45, 2012.

Malm, J., Grahn, L., Mironov, D., and Terzhevik, A.: Field investigation of the thermal bar in Lake Ladoga, spring 1991, Hydrol. Res., 24, 339-358, 1993.

Margalef, R.: Some concepts relative to the organization of plankton, Oceanogr. Mar. Biol. Ann. Rev., 5, 257-289, 1967.

McDougall, T. J.: Thermobaricity, cabbeling, and water-mass conversion, J. Geophys. Res., 92, 5448-5464, 1987.

Mikkola, H.: Implication of alien species introduction to loss of fish biodiversity and livelihoods on Issyk-Kul Lake in Kyrgyzstan, in: Biodiversity Enrichment in a Diverse World, edited by: Lameed, G. A., InTech Press, Rijeka, Croatia, ISBN-13: 978953-51-0718-7, 395-419, 2012.

Oberhänsli, H. and Molnar, P.: Climate Evolution in Central Asia during the Past Few Million Years: A Case Study from Issyk Kul, Sci. Dril., 13, 51-57, https://doi.org/10.2204/iodp.sd.13.09.2011, 2012.

Palmer, S. C. J., Pelevin, V. V., Goncharenko, I., Kovács, A. W., Zlinszky, A., Présing, M., Horváth, H., Nicolás-Perea, V., Balzter, H., and Tóth, V. R.: Ultraviolet fluorescence LiDAR (UFL) as a measurement tool for water quality parameters in turbid lake conditions, Remote Sens., 5, 4405-4422, https://doi.org/10.3390/rs5094405, 2013.

Pelevin, V., Zlinszky, A., Khimchenko, E., and Toth, V.: Ground truth data on chlorophyll-a, chromophoric dissolved organic matter and suspended sediment concentrations in the upper water layer as obtained by UFL LiDAR at high spatial resolution, Int. J. Remote Sens., 38, 7, 1967-1982, https://doi.org/10.1080/01431161.2016.1274446, 2017.

Peeters, F., Finger, D., Hofer, M., Brennwald, M., Livingstone, D. M., and Kipfer, R.: Deep-water renewal in Lake Issyk-Kul driven by differential cooling, Limnol. Oceanogr., 48, 1419$1431,2003$.
Romanovsky, V. V.: Lake Issyk-Kul as natural complex. Ilim, Frunze, 164 pp., 1991 (in Russian).

Romanovsky, V. V.: Water level variations and water balance of Lake Issyk-Kul, in: Lake Issyk-Kul: its natural environment, edited by: Klerkx, J. and Imanackunov, B., NATO Science Series, Kluwer Academic Publishers, Netherlands, Earth and Environmental Sciences, 13, 45-58, 2002.

Romanovsky, V. V., Tashbaeva, S., Creteaux, J.-F., Calmant, S., and Drolon, V.: The closed lake Issyk-Kul as an indicator of global warming in Tien-Shan, Natural Science, 5, 608-623, https://doi.org/10.4236/ns.2013.55076, 2013.

Schmid, M., Budnev, N. M., Granin, N. G., Sturm, M., Schurter, M., and Wüest, A.: Lake Baikal deepwater renewal mystery solved, Geophys. Res. Lett., 35, L09605, https://doi.org/10.1029/2008GL033223, 2008.

Schmitt, R. W.: Double diffusion in oceanography, Annu. Rev. Fluid Mech., 26, 255-285, 1994.

Shimaraev, M. N., Granin, N. G., and Zhdanov, A. A.: Deep ventilation of Lake Baikal waters due to spring thermal bars, Limnol. Oceanogr., 38, 1068-1072, 1993.

Shirshov Institute of Oceanology: Ocean-Land Interactions Laboratory data repository, Russian Academy of Sciences, available at: https://land.ocean.ru/en/data-for-downloads, last access: 4 December 2018.

Tuzhilkin, V.: Some features of the Black Sea seasonal thermohaline variability: Modern view, Geography, Environment, Sustainability, 3, 42-50, https://doi.org/10.24057/2071-9388-2010-3-242-50, 2010.

Ullman, D., Brown, J., Cornillon, P., and Mavor, T.: Surface temperature fronts in the Great Lakes, J. Great Lakes Res., 24, 753-775, 1998.

Wozniak, B. and Dera, J.: Light Absorption in Sea Water, Springer, 454 pp., 2007.

Zavialov, P. O., Pelevin, V. V., Belyaev, N. A., Izhitskiy, A. S., Konovalov, B. V., Krementskiy, V. V., Goncharenko, I. V., Osadchiev, A. A., Soloviev, D. M., Garcia, C. A. E., Pereira, E. S., Sartorato, L., and Moller Jr., O. O.: High resolution LiDAR measurements reveal fine internal structure and variability of sediment-carrying coastal plume, Estuar. Coast. Shelf S., 205, 40-45, https://doi.org/10.1016/j.ecss.2018.01.008, 2018.

Zilitinkevich, S. S., Kreiman, K. D., and Terzhevik, A. Y.: The thermal bar, J. Fluid Mech., 236, 27-42, 1992. 